University of Nebraska - Lincoln

DigitalCommons@University of Nebraska - Lincoln

\title{
Evaluation and comparison of gross primary production estimates for the Northern Great Plains grasslands
}

\author{
Li Zhang \\ U.S. Geological Survey (USGS), lizhang@usgs.gov \\ Bruce K. Wylie \\ USGS EROS, wylie@usgs.gov \\ Thomas Loveland \\ USGS/EROS, loveland@usgs.gov \\ Eugene A. Fosnight \\ USGSEROS, fosnight@usgs.gov \\ Larry L. Tieszen \\ USGSEROS, tieszen@usgs.gov \\ See next page for additional authors
}

Follow this and additional works at: https://digitalcommons.unl.edu/usgsstaffpub

Part of the Geology Commons, Oceanography and Atmospheric Sciences and Meteorology Commons, Other Earth Sciences Commons, and the Other Environmental Sciences Commons

Zhang, Li; Wylie, Bruce K.; Loveland, Thomas; Fosnight, Eugene A.; Tieszen, Larry L.; Ji, Lei; and Gilmanov, Tagir G., "Evaluation and comparison of gross primary production estimates for the Northern Great Plains grasslands" (2007). USGS Staff -- Published Research. 633.

https://digitalcommons.unl.edu/usgsstaffpub/633

This Article is brought to you for free and open access by the US Geological Survey at DigitalCommons@University of Nebraska - Lincoln. It has been accepted for inclusion in USGS Staff -- Published Research by an authorized administrator of DigitalCommons@University of Nebraska - Lincoln. 


\section{Authors}

Li Zhang, Bruce K. Wylie, Thomas Loveland, Eugene A. Fosnight, Larry L. Tieszen, Lei Ji, and Tagir G. Gilmanov

This article is available at DigitalCommons@University of Nebraska - Lincoln: https://digitalcommons.unl.edu/ usgsstaffpub/633 


\title{
Evaluation and comparison of gross primary production estimates for the Northern Great Plains grasslands
}

\author{
Li Zhang ${ }^{\mathrm{a}, *}$, Bruce Wylie ${ }^{\mathrm{a}}$, Thomas Loveland ${ }^{\mathrm{b}}$, Eugene Fosnight ${ }^{\mathrm{a}}$, \\ Larry L. Tieszen ${ }^{\mathrm{b}}$, Lei $\mathrm{Ji}^{\mathrm{a}}$, Tagir Gilmanov ${ }^{\mathrm{c}}$ \\ ${ }^{a}$ Science Applications International Corporation (SAIC), U.S. Geological Survey (USGS), \\ Center for Earth Resources Observation and Science (EROS), Sioux Falls, SD 57198, USA \\ ${ }^{\mathrm{b}}$ USGS/EROS, Sioux Falls, SD 57198, USA \\ c South Dakota State University, Brookings, SD 57007, USA
}

Received 1 May 2006; received in revised form 11 August 2006; accepted 12 August 2006

\begin{abstract}
Two spatially-explicit estimates of gross primary production (GPP) are available for the Northern Great Plains. An empirical piecewise regression (PWR) GPP model was developed from flux tower measurements to map carbon flux across the region. The Moderate Resolution Imaging Spectrometer (MODIS) GPP model is a process-based model that uses flux tower data to calibrate its parameters. Verification and comparison of the regional PWR GPP and the global MODIS GPP are important for the modeling of grassland carbon flux. This study compared GPP estimates from PWR and MODIS models with five towers in the grasslands. Among them, PWR GPP and MODIS GPP showed a good agreement with tower-based GPP at three towers. The global MODIS GPP, however, did not agree well with tower-based GPP at two other towers, probably because of the insensitivity of MODIS model to regional ecosystem and climate change and extreme soil moisture conditions. Crossvalidation indicated that the PWR model is relatively robust for predicting regional grassland GPP. However, the PWR model should include a wide variety of flux tower data as the training data sets to obtain more accurate results.

In addition, GPP maps based on the PWR and MODIS models were compared for the entire region. In the northwest and south, PWR GPP was much higher than MODIS GPP. These areas were characterized by the higher water holding capacity with a lower proportion of $\mathrm{C}_{4}$ grasses in the northwest and a higher proportion of $\mathrm{C}_{4}$ grasses in the south. In the central and southeastern regions, PWR GPP was much lower than MODIS GPP under complicated conditions with generally mixed $\mathrm{C}_{3} / \mathrm{C}_{4}$ grasses. The analysis indicated that the global MODIS GPP model has some limitations on detecting moisture stress, which may have been caused by the facts that $\mathrm{C}_{3}$ and $\mathrm{C}_{4}$ grasses are not distinguished, water stress is driven by vapor pressure deficit (VPD) from coarse meteorological data, and MODIS land cover data are unable to differentiate the sub-pixel cropland components.
\end{abstract}

(C) 2006 Elsevier Inc. All rights reserved.

Keywords: Carbon flux; Decision tree; Grassland; Gross primary production (GPP); MODIS GPP; Model comparison; Northern Great Plains

\section{Introduction}

Numerous studies have been conducted to investigate $\mathrm{CO}_{2}$ exchange between the biosphere and atmosphere at regional, continental, and global scales. Each method has distinct advantages and disadvantages. In the mid-1990s, the Interna-

\footnotetext{
* Corresponding author.

E-mail address: lizhang@usgs.gov (L. Zhang).
}

tional Geosphere-Biosphere Programme (IGBP) proposed a global network of flux towers to monitor long-term and continuous $\mathrm{CO}_{2}$ fluxes associated with diverse biomes and climate regions (Baldocchi et al., 2001). At present, more than 300 flux towers are registered on the FLUXNET network that coordinates regional and global analysis of observations from micrometeorological tower sites (http://www.fluxnet.ornl.gov/ fluxnet/). Flux towers measure net ecosystem exchange (NEE) over hourly to daily time scales, and $\mathrm{CO}_{2}$ fluxes can be integrated into seasonal and yearly estimates for a variety of 
ecosystems (Baldocchi et al., 2001; Goulden et al., 1996). Flux tower measurements also provide accurate ground-truth data for calibrating and validating gross primary production (GPP) and net primary production (NPP) products from predictive models (Turner et al., 2003, 2005; Xiao et al., 2004). Among the networks of flux towers, the AmeriFlux and AgriFlux programs were established to improve understanding of carbon pools and fluxes in North America. The AmeriFlux network, part of the FLUXNET program, uses the eddy covariance technique to measure the exchange of $\mathrm{CO}_{2}$, water vapor, and energy between terrestrial ecosystems and the atmosphere (http://public.ornl. gov/ameriflux/). The AgriFlux network, developed by the U.S. Department of Agriculture (USDA), Agricultural Research Service (ARS), uses both the Bowen ratio-energy balance (BREB) and eddy covariance techniques (Raupach, 1988) to measure the effects of environmental conditions and agricultural management decisions on carbon exchange between land and atmosphere.

Since the early 1980s, vegetation index data sets have been produced from a number of sensors, such as the Advanced Very High Resolution Radiometer (AVHRR), Moderate Resolution Imaging Spectroradiometer (MODIS), and SPOT VEGETATION. Vegetation index data sets provide the opportunity for studying and monitoring global vegetation conditions in terrestrial ecosystems (Tucker, 1996). Models have been developed for estimating vegetation production at global and regional scales. These models combine $\mathrm{CO}_{2}$ flux measurements at flux towers with satellite-based, remotely sensed observations, and range in complexity from "data-driven" empirical models to "process-based" biogeochemical models (Parton et al., 1993; Potter et al., 1993; Turner et al., 2004; Wylie et al., 2004; Xiao et al., 2004). Predictive models require evaluation of their performance in comparison with data sets from groundbased measurements (Amthor et al., 2001; Kramer et al., 2002; Veroustraete et al., 2002) and other model results (VEMAP Members, 1995). Goulden et al. (1996) stated that the long-term carbon flux measurements collected at flux towers are well suited for developing and testing mechanistic models. However, validation of estimated GPP is limited by the lack of extensive flux tower observations over large areas. Model intercomparison has been used as an alternative method for indirect validation and identification of model weaknesses and inconsistencies where ground observations are lacking. A global terrestrial monitoring network integrating flux tower measurements with carbon-cycle models and National Aeronautics and Space Administration (NASA) Earth Observing System (EOS) satellite data has been established to improve the accurate monitoring and better understanding of global carbon fluxes and to provide consistent checks and validation of each source (Running et al., 1999).

Grasslands cover nearly one-fifth of the global terrestrial surface (Eswaran et al., 1993) and store most of their carbon below ground (Burke et al., 1997; Connor et al., 2001). The carbon flux and dynamics on grasslands are important to the global carbon cycle. However, the contributions of grasslands to local and regional carbon budgets remain uncertain (Novick et al., 2004), largely due to the lack of carbon flux data for grassland ecosystems. We have developed a remote sensingbased piecewise regression (PWR) model to estimate grassland and shrubland GPP in the Northern Great Plains and Northern Kazakhstan (Wylie et al., 2004, in press). This model was developed to spatially extrapolate local flux tower measurements across landscapes or regions with similar land cover types.

This study continues our efforts to develop a robust estimation capability of GPP for grassland and shrubland and, specifically, verifies the grassland GPP estimates from the PWR model in the Northern Great Plains during the growing season (April-October). The specific research objectives are to 1) compare GPP estimates from the PWR and the MODIS models (Collection 4.5) with GPP derived from measurements at five flux towers; 2) evaluate the PWR model for predicting GPP for grasslands in this region; 3) compare the spatial patterns of GPP estimates for grasslands from the PWR and MODIS models in the Northern Great Plains; and 4) explore the variables and their interactions that may explain differences in the GPP estimates generated by the PWR and MODIS GPP models.

\section{Study area and GPP models}

\subsection{Study area and flux towers}

The study area encompasses the Northwestern Glaciated Plains, Northwestern Great Plains, and Western High Plains, as defined by Omernik's level III ecoregions (Omernik, 1987), including parts of North Dakota, South Dakota, Nebraska, Montana, Wyoming, and the adjacent Canadian area (Fig. 1). Based on the 30-year (1971-2000) Normals (High Plains Regional Climate Center, http://www.hprcc.unl.edu/), the mean annual precipitation in this region ranges from 380 millimeters $(\mathrm{mm})$ in the west to $640 \mathrm{~mm}$ in the southeast. The mean annual temperature ranges from $4{ }^{\circ} \mathrm{C}$ in the north to $13{ }^{\circ} \mathrm{C}$ in the south. Grassland constitutes the major land cover in the Northern Great Plains. The grasses transit from wheatgrass (Agropyron sp.), green needlegrass (Stipa spartea), grama grass (Bouteloua sp.), and buffalo grass (Buchloe dactylides) in the north to grama and buffalo grass in the south (Omernik, 1987).

There are five flux towers in the grasslands of the Northern Great Plains (Fig. 1). The two AmeriFlux towers (Lethbridge, Canada, 2000-2001; Fort Peck, MT, 2000) use the eddy covariance technique, and the three AgriFlux towers (Mandan, ND, 2000-2001; Miles City, MT, 2000-2001; and Cheyenne, WY, 1998) use the BREB technique (Table 1). Both the eddy covariance and the BREB methods have been shown to provide accurate measurements of carbon flux in the short stature plant communities of the Northern Great Plains (Gilmanov et al., 2005) and in four Southern Plains (Gilmanov et al., 2003), indicating no substantial differences on the GPP and respiration estimates generated with eddy covariance and BREB methods. BREB flux measurements have been used to quantify carbon dynamics of low stature vegetation in numerous studies (Emmerich, 2003; Frank, 2004; Sims \& Bradford, 2001). Angell et al. (2001) found that the BREB and closed chamber measurements showed good agreement and could be used in concert to obtain reliable estimates of $\mathrm{CO}_{2}$ flux in the Sagebrush 


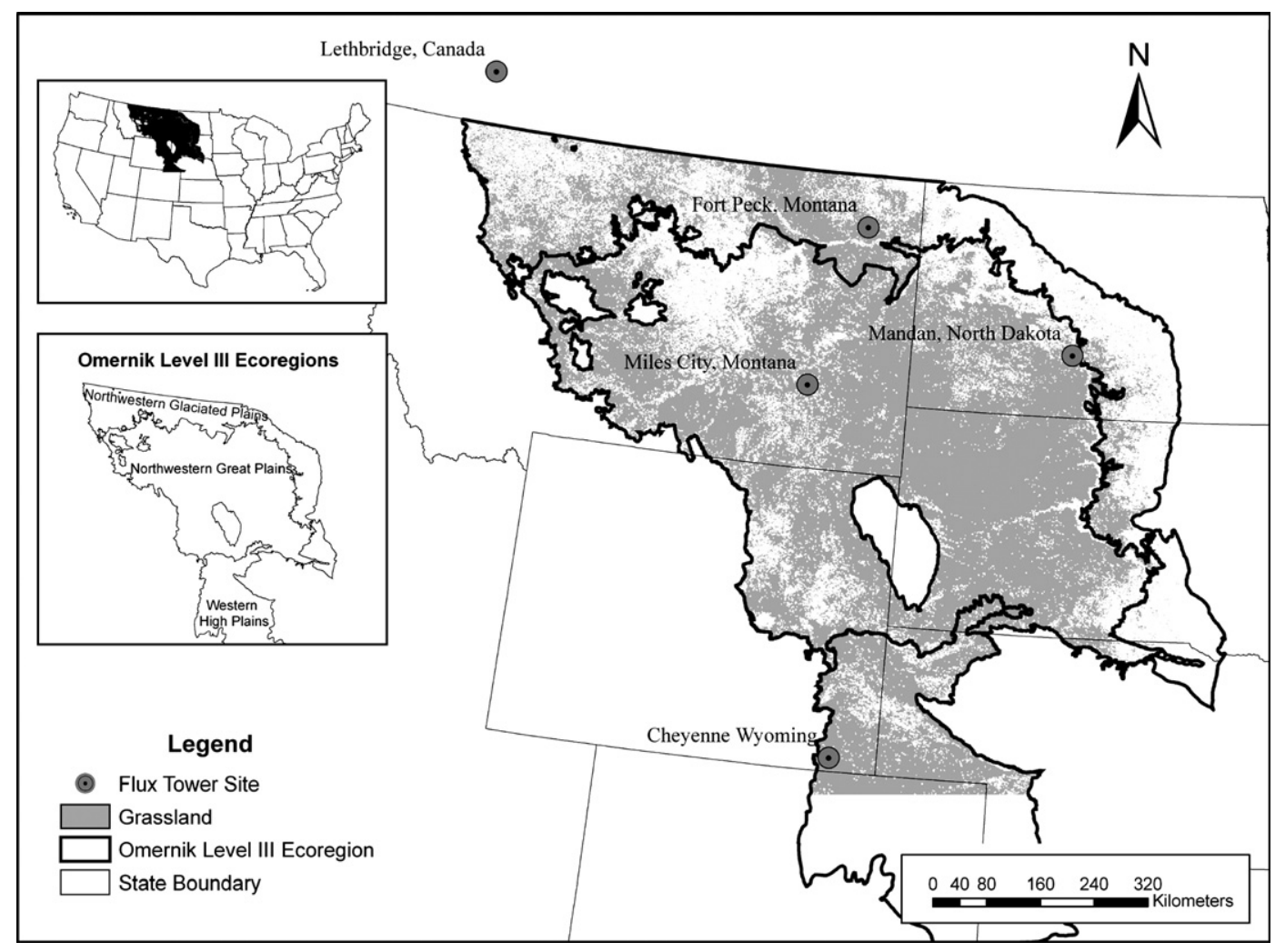

Fig. 1. Grassland flux towers in the Northern Great Plains.

steppe ecosystem. The latent heat fluxes from the BREB and eddy covariance methods were in a good agreement with a low bias and high correlation for the wet sloping grassland (Pauwels \& Samson, 2006). Gilmanov also compared the basic ecophysiological characteristics obtained using light-response analysis of flux data from BREB and eddy covariance towers of this study area, and this comparison does not show any significant differences in basic ecophysiological parameters.

In this study, we used local measurements of carbon flux collected at each flux tower to derive GPP for model input and validation. The tower-based GPP estimates were calculated from estimated daytime respiration and NEE using lightresponse function analysis (Gilmanov et al., 2005). This method has been applied to flux tower data in the Northern Great Plains
(Gilmanov et al., 2005), Central Asia (Gilmanov et al., 2004), and four Southern Plains ecosystems (Gilmanov et al., 2003).

\subsection{Model descriptions}

\subsubsection{The empirical PWR model}

Empirical models have been developed to relate GPP, NPP, and NEE to variables that influence plant production. The Miami model (Lieth, 1975) is the best known empirical model for estimating NPP from mean annual precipitation and surface temperature. The PWR model (Wylie et al., 2004; in press) was developed to extrapolate grassland flux tower measurements to grassland regions and to reveal relationships between GPP and multiple environmental variables. Although the PWR model

Table 1

Descriptions of flux tower sites (adapted from Gilmanov et al., 2005)

\begin{tabular}{|c|c|c|c|c|c|c|c|}
\hline Site and year & Ecosystem & Latitude, longitude & Elevation (m) & Annual precipitation $(\mathrm{mm})$ & $\begin{array}{l}\text { Mean temperature } \\
\text { January/July }\left({ }^{\circ} \mathrm{C}\right)\end{array}$ & Sensor & Principal investigator \\
\hline $\begin{array}{l}\text { Lethbridge } \\
\quad 2000-2001\end{array}$ & $\begin{array}{l}\text { Northern mixed-short } \\
\text { grass prairie }\end{array}$ & $49^{\circ} 42^{\prime} \mathrm{N} 112^{\circ} 56^{\prime} \mathrm{W}$ & 960 & 378 & $-8.6 / 18.0$ & $\begin{array}{l}\text { Eddy- } \\
\text { covariance }\end{array}$ & Flanagan, L. B. \\
\hline $\begin{array}{l}\text { Fort Peck } \\
2000\end{array}$ & Northern mixed prairie & $48^{\circ} 18^{\prime} \mathrm{N} 105^{\circ} 06^{\prime} \mathrm{W}$ & 634 & 310 & $-11.9 / 18.0$ & $\begin{array}{l}\text { Eddy- } \\
\text { covariance }\end{array}$ & Meyers, T. P. \\
\hline $\begin{array}{l}\text { Mandan } \\
\quad 2000-2001\end{array}$ & Mixed prairie & $46^{\circ} 46^{\prime} \mathrm{N} 100^{\circ} 55^{\prime} \mathrm{W}$ & 518 & 404 & $-8.7 / 23.5$ & BREB & Frank, A. B. \\
\hline $\begin{array}{l}\text { Miles City } \\
\quad 2000-2001\end{array}$ & Northern mixed prairie & $46^{\circ} 18^{\prime} \mathrm{N} 105^{\circ} 58^{\prime} \mathrm{W}$ & 719 & 343 & $-12.2 / 21.2$ & BREB & Haferkamp, M. R. \\
\hline $\begin{array}{c}\text { Cheyenne } \\
1998\end{array}$ & Mixed prairie & $41^{\circ} 11^{\prime} \mathrm{N} 104^{\circ} 54^{\prime} \mathrm{W}$ & 1910 & 397 & $-2.5 / 17.5$ & BREB & Morgan, J. A. \\
\hline
\end{tabular}


does not explicitly model biogeochemical processes, and differs from other mechanistic models that are based on plant physiological responses, it reveals valuable, implicit insights into the conditions under which plant productivity is strongly influenced. The spatial and temporal variation in the flux measurements at towers cannot represent the variability in all different landscapes, so conclusions drawn from the site flux data alone should not be extrapolated beyond reasonable inferences (Wylie et al., 2003).

The PWR model was applied to derive an empirical relationship between independent variables and tower-based GPP at the five flux towers in multiple years at 10-day intervals. A series of rules were produced and regression equations were fit to the data bounded by the stratified rules. The PWR equations were then applied through time and space to estimate 10-day GPP across the study area. The inputs are 10-day composite SPOT VEGETATION (http://free.vgt.vito.be) normalized difference vegetation index (NDVI) data at $1-\mathrm{km}$ resolution, daily precipitation data at $0.25^{\circ}$ resolution and daily temperature data at $0.5^{\circ}$ resolution (the daily meteorological data (Xie \& Arkin, 1996) was summed to 10-day time interval), phenological metrics at 1-km resolution (Reed et al., 1994), and proportion of $\mathrm{C}_{4}$ grasses (Tieszen et al., 1997). NDVI, which has been shown to be quantitatively related to GPP (Gilmanov et al., 2005), is used as a key input for the PWR model. The phenological metrics were calculated from a time series of SPOT VEGETATION NDVI data. The metrics used in the PWR model included the day of the start of the growing season (SOST), NDVI value at the start of the growing season (SOSN), and seasonally time-integrated NDVI (TIN). Precipitation and temperature were acquired from the National Oceanic and Atmospheric Administration (NOAA) Climate Prediction Center, and photosynthetically active radiation (PAR) was obtained from NOAA National Environmental Satellite, Data and Information Service (NESDIS) (http://www.atmos.umd. $\mathrm{edu} / \sim \mathrm{srb} / \mathrm{gcip} /$ ). The proportion of $\mathrm{C}_{4}$ grasses is derived from the State Soil Geographic (STATSGO) database at a scale of 1:250,000, which represents the percentage of vegetation using the $\mathrm{C}_{4}$ photosynthetic pathway.

\subsubsection{MODIS GPP model}

The MODIS sensors aboard Terra (EOS AM), launched in December 1999, and Aqua (EOS PM), launched in May 2002, have provided measurements of spatial and temporal variation in productivity (Huete et al., 2002; Justice et al., 1998). MODIS data have been used to estimate 8-day summations of GPP and annual NPP at 1-km resolution since March 2000 (Heinsch et al., 2003; Justice et al., 1998; Running et al., 2004). The MODIS GPP algorithm employs a light use efficiency (LUE) approach. The major inputs of the MODIS GPP algorithm include MODIS land cover products (MOD12Q1), MODIS leaf area index (LAI) and fraction of photosynthetically active radiation (FPAR) (MOD15A2), meteorological data at $1^{\circ} \times 1.25^{\circ}$ resolution from the NASA Data Assimilation Office (DAO), and parameters from the Biome Parameter Look-up Table (Heinsch et al., 2003). The MODIS GPP product (Collection 4.5) is available from the Numerical Terradynamic
Simulation Group, College of Forestry and Conservation, The University of Montana (http://www.ntsg.umt.edu/).

\section{Methods}

\subsection{Regression and agreement analysis}

The Pearson's correlation coefficient ( $r$ ), root mean square error (RMSE), and Willmott's index of agreement $(d)$ were used to quantify model agreement. In this study, RMSE is a measure of actual difference between two data sets for all samples, which is given by

$\mathrm{RMSE}=\frac{1}{n} \sum_{i=1}^{n}\left(X_{i}-Y_{i}\right)^{2}$

Willmott's index of agreement $(d)(1981,1982)$ is defined as

$d=1-\frac{\sum_{i=1}^{n}\left(X_{i}-Y_{i}\right)^{2}}{\sum_{i=1}^{n}\left(\left|X_{i}-\bar{X}\right|+\left|Y_{i}-\bar{X}\right|\right)^{2}}$

where $X_{i}$ is the observed value, $Y_{i}$ is the estimated value, and $\bar{X}$ is the mean of observed values. As a non-dimensional measure, $d$ is bounded below by 0 and above by 1 . When two data sets are in perfect agreement, $d$ equals 1 . Willmott's index of agreement is designed for model validation. It is also capable of measuring two types of errors, that is, unsystematic and systematic errors. Unsystematic error quantifies measurement accuracy, which is associated with random error between the points and the 1:1 line built from the two data sets. Systematic error quantifies the precision of the measurement, which can be potentially reduced by applying regression function to the data sets.

The numerator of the main term of Eq. (2) is the sum of the squared error (SSE). The mean value of SSE is the mean square error (MSE). Willmott defined the systematic MSE $\left(\mathrm{MSE}_{\mathrm{s}}\right)$ as

$\operatorname{MSE}_{s}=\frac{1}{n} \sum_{i=1}^{n}\left(X_{i}-\hat{Y}_{i}\right)^{2}$

and the unsystematic MSE (MSE $\mathrm{u}_{\mathrm{u}}$ as

$\operatorname{MSE}_{u}=\frac{1}{n} \sum_{i=1}^{n}\left(Y_{i}-\hat{Y}_{i}\right)^{2}$

where $\hat{Y}$ is the predicted $Y$ value obtained from regression model $\hat{Y}=a+b X$. The sum of $\mathrm{MSE}_{\mathrm{s}}$ and $\mathrm{MSE}_{\mathrm{u}}$ is MSE:

$\mathrm{MSE}=\mathrm{MSE}_{s}+\mathrm{MSE}_{u}$

The proportion of systematic and unsystematic errors to total errors can be derived from $\mathrm{MSE}_{\mathrm{s}} / \mathrm{MSE}$ and $\mathrm{MSE}_{\mathrm{u}} / \mathrm{MSE}$. 


\subsection{Comparison of PWR GPP and MODIS GPP with tower- based GPP}

For each flux tower location, we extracted GPP values from the 1-km PWR GPP maps for each 10-day interval during the 1998 and 2001 growing season and from the 1-km MODIS GPP maps for each 8-day interval during the 2000 and 2001 growing seasons. To keep the temporal resolutions consistent, the towerbased GPP were integrated to the 10-day interval GPP when compared with PWR GPP, and integrated to 8-day interval GPP when compared with MODIS GPP. The PWR GPP and MODIS GPP were compared with tower-based GPP using Pearson's correlation coefficient and Willmott's $d$ to verify the ability of the model estimates to capture the seasonal dynamics of vegetation productivity measured at the flux towers.

\subsection{Cross-validation of PWR GPP at flux tower sites}

Cross-validation was applied to evaluate the predictive accuracy of the PWR model. In cross-validation, data were divided into two portions: one (training samples) for PWR model development and the other (testing samples) for model verification. Each combination of site and year (site-year) was successively withheld as the testing sample, then GPP was predicted for the withheld site-year from the data for the remaining site-years (the training samples). The model estimates were tested at the withheld site.

\subsection{Intercomparison of the PWR GPP and MODIS GPP maps}

The two estimated GPP maps were compared to determine and understand the differences between the two GPP model estimates. We randomly sampled 2951 pixels within the grassland pixels, and 1-km GPP values were extracted from PWR GPP and MODIS GPP maps. We performed Pearson's correlation coefficient and Willmott's $d$ analyses to evaluate the agreement of the two GPP estimates.

\subsection{Ecosystem characteristics contributing to GPP difference patterns}

Interactions among ecosystem characteristics, including the proportion of $\mathrm{C}_{4}$ grasses, soil water holding capacity, percentage of clay, and percentage of cropland mixed in grassland, were explored using a decision tree technique. These interactions may contribute to the spatial patterns in a difference image of the two model estimates of GPP (MODIS GPP minus PWR GPP).

This analysis was restricted to grasslands as identified by MODIS land cover (MOD12Q1) Type 2 data. PWR GPP and MODIS GPP were temporally integrated into total GPP for the growing seasons of 2000 and 2001. A decision tree method (Breiman et al., 1984) was used to identify the variables that could explain the GPP difference patterns and to detect spatial structure in the relationships between the environmental variables and the GPP difference patterns. The decision tree is based on a tree-like structure to determine a set of if-then logical conditions that permit accurate prediction and classification. The number of decision tree nodes, or tree complexity, was constrained by defining the minimum number of training cases needed to form a new node. The limited tree segmentation reduced tree size, simplified tree structure, retained predictive accuracy, reduced over-fitting, and ignored information that was not significant. The simplified trees improved the interpretation and understanding of the relationships between GPP difference patterns and the ecosystem characteristics.

The decision tree analyses were conducted using See ${ }^{1}$ (http://www.rulequest.com/) decision tree software. The analysis included those ecosystem characteristics that we determined to be potentially significant to GPP differences between the two model estimates. The ecosystem characteristics were 1) soil data derived from STATSGO, including water holding capacity (denoted as WHC) and percentage of clay (denoted as Clay) and, 2) percentage of cropland per pixel (denoted as Crop) derived from the 30-m National Land Cover Dataset (NLCD 1992; http:/www.mrlc.gov/). The spatial patterns represented by relationships between different ecosystem characteristics and GPP difference patterns were mapped over the region as defined by the decision tree rules.

\section{Results and discussion}

\subsection{Comparisons of PWR GPP and MODIS GPP with tower- based GPP}

Fig. 2 shows the relationships between the PWR GPP model estimates and tower-based GPP. Similarly, Fig. 3 shows the relationships between the MODIS GPP model estimates and tower-based GPP. Low unsystematic error (high precision) is represented by plots that have estimates close to the regression line. Low systematic error (high accuracy) is represented by plots that have estimates close to the 1:1 line. All the four sites have very high $r$ and $d$ values between PWR GPP and towerbased GPP (Fig. 2 and Table 2). The proportion of the error in most site-years is mainly dominated by unsystematic error, suggesting the results are unbiased, whereas the proportion of error in Miles City 2000 is mainly dominated by systematic error, suggesting the results may be biased-in this case, the PWR model underestimates GPP at higher values. At the Lethbridge site, GPP estimates from PWR model were unavailable due to the lack of mapped meteorological data in Canada. The tower-based GPP and meteorological data measured at Lethbridge tower were used as the training data for developing the PWR model.

Both Fort Peck and Mandan have high $r$ and $d$ values between MODIS GPP and tower-based GPP (Fig. 3 and Table 3). The proportion of the error in Mandan is mainly dominated by unsystematic error. At the Lethbridge and Miles City sites, the estimates appear to have some remnant nonlinear effects, likely caused by drought-driven hysteresis that is not represented in the

\footnotetext{
${ }^{1}$ Any use of trade, product, or firm names is for description purposes only and does not imply endorsement by the U.S. Government.
} 

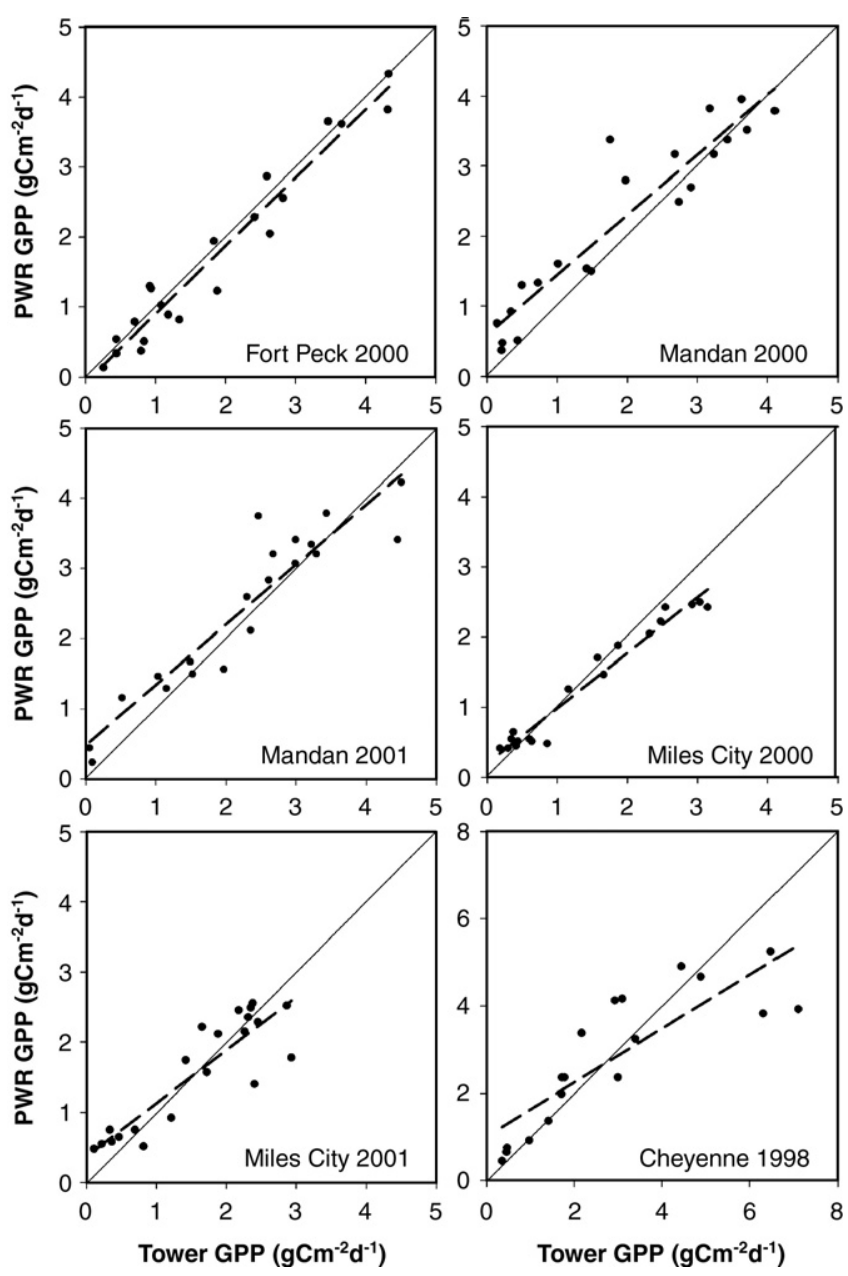

Fig. 2. Comparisons between PWR GPP and tower-based GPP during the growing season at flux towers (10-day interval). The dashed line represents the regression line. The solid line represents the $1: 1$ line.

MODIS model, in which water stress is driven by vapor pressure deficit (VPD). The proportion of the error is mainly dominated by systematic error, suggesting the results may be biased in a consistent way. The PWR model used data sets from the five flux towers to develop the empirical model and produce GPP maps in the ecoregions. The MODIS GPP model, however, probably did not use all of these flux tower data sets to calibrate and parameterize the algorithm, which may cause the estimates to be less sensitive to local climate variation.

At the Fort Peck and Mandan sites, there was good agreement for both MODIS and PWR GPP with tower-based GPP (Fig. 4). Both MODIS and PWR GPP tracked the seasonal dynamics of tower-based GPP well, but the MODIS model underestimated GPP from June to July at the Fort Peck site. At the Lethbridge site, MODIS GPP failed to capture seasonal dynamics. In 2000, MODIS GPP showed later initiation and later cessation of the growing season than tower-based GPP. In 2001, MODIS GPP captured the onset of the growing season, but failed to capture the peak and the end of the growing season. In both years, tower-based GPP dropped sharply after mid-June, which was not reflected by MODIS GPP until the end of July. MODIS GPP had a much lower maximum GPP than the tower- based GPP. At the Miles City site, PWR GPP had a better agreement with tower-based GPP than MODIS GPP, which lagged during the growing season in 2000, but captured seasonal dynamics well in 2001. MODIS GPP tended to overestimate GPP in 2000, but underestimated GPP in 2001. At the Cheyenne site in 1998, PWR GPP captured the onset and end of the growing season well, but underestimated GPP during June and July.

The deviation of model estimates from flux tower measurements may be caused by errors from pixel misregistration, flux tower estimates, and model estimates. The GPP difference was probably related to mismatch in scale when comparing tower-
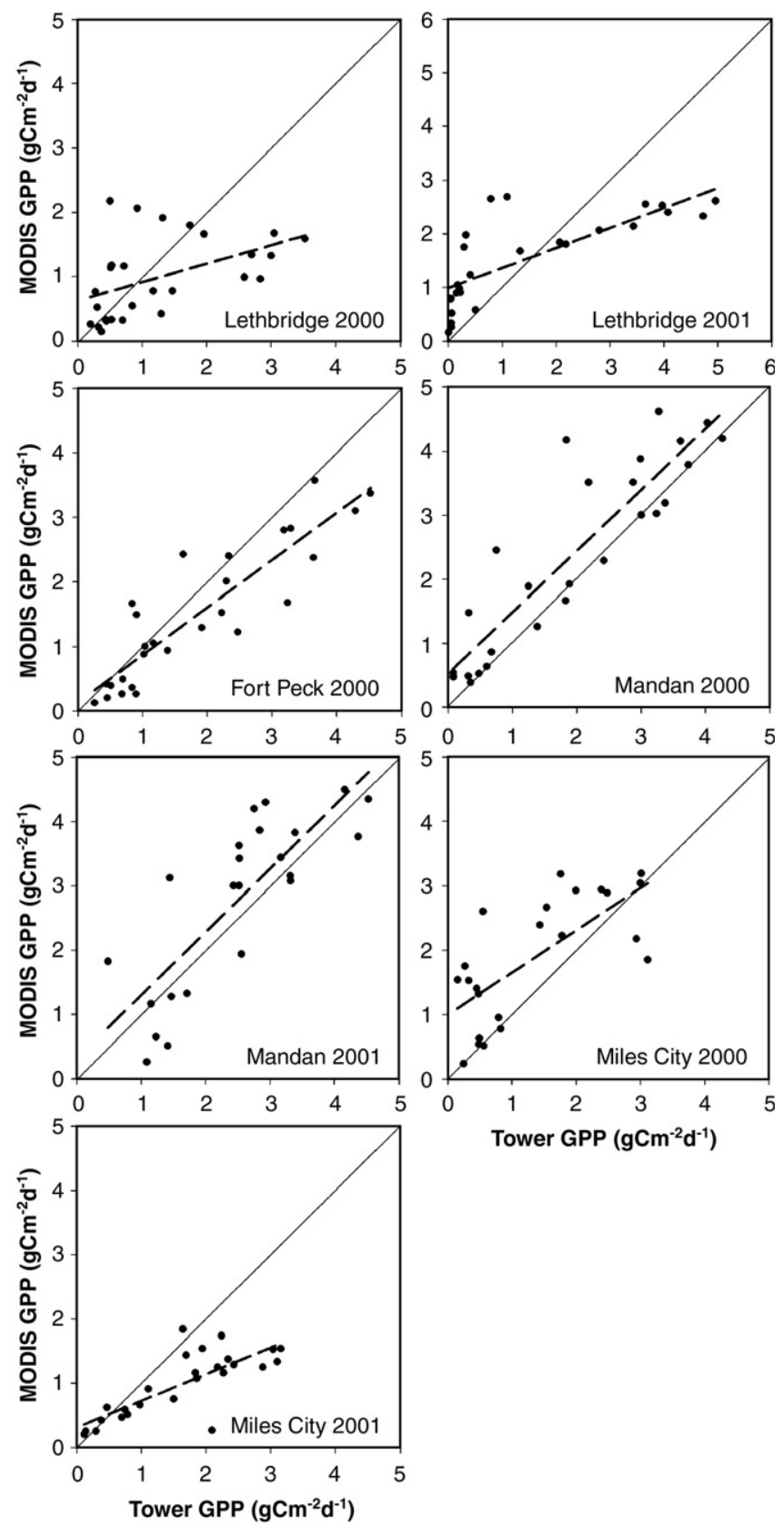

Tower GPP $\left(\mathrm{gCm}^{-2} \mathrm{~d}^{-1}\right)$

Fig. 3. Comparisons between MODIS GPP and tower-based GPP during the growing season at flux towers (8-day interval). The dashed line represents the regression line. The solid line represents the 1:1 line. 
Table 2

Agreement analysis of tower-based GPP and PWR GPP

\begin{tabular}{|c|c|c|c|c|c|c|}
\hline Parameters & Fort Peck 2000 & Mandan 2000 & Mandan 2001 & Miles City 2000 & Miles City 2001 & Cheyenne 1998 \\
\hline$n$ (Observations) & 21 & 21 & 20 & 19 & 21 & 18 \\
\hline Mean of Tower GPP $(\bar{T})$ & 1.85 & 1.90 & 2.25 & 1.41 & 1.57 & 2.93 \\
\hline Mean of PWR GPP $(\bar{P})$ & 1.73 & 2.21 & 2.41 & 1.31 & 1.56 & 2.81 \\
\hline$r$ & 0.97 & 0.94 & 0.93 & 0.98 & 0.88 & 0.84 \\
\hline Regression ${ }^{\mathrm{a}}$ slope & 0.97 & 0.86 & 0.86 & 0.79 & 0.76 & 0.62 \\
\hline Regression $^{\mathrm{a}}$ intercept & -0.08 & 0.58 & 0.49 & 0.19 & 0.37 & 1.00 \\
\hline $\mathrm{MSE}_{\mathrm{S}} / \mathrm{MSE}(\%)$ & 16 & 43 & 26 & 68 & 27 & 49 \\
\hline $\mathrm{MSE}_{\mathrm{u}} / \mathrm{MSE}(\%)$ & 84 & 57 & 74 & 32 & 73 & 51 \\
\hline
\end{tabular}

a Tower-based GPP is the independent variable, and PWR GPP is the dependent variable.

based GPP with the 1-km resolution PWR GPP and MODIS GPP. Previous studies have found pixel misregistration problems with MODIS data, but the geolocation error is approximately $50 \mathrm{~m}$ at nadir (Wolfe et al., 2002). Tower-based GPP represents a small, unfixed footprint that changes in size and shape as a function of wind speed, wind direction, surface roughness, and atmospheric stability (Schmid, 2002). The 1-km pixel of PWR GPP and MODIS GPP may not exactly overlay the tower footprint. As long as the flux towers are located in the fairly large and uniform rangelands, the pixel values extracted at the flux tower sites can represent the environmental conditions in the surrounding areas.

Tower-based GPP is another source of error. The respiration estimate may have uncertainties that could propagate to the GPP estimate (Goulden et al., 1996; Turner et al., 2003). Flux towers directly measure NEE, while daily GPP is the difference between NEE and ecosystem respiration during the daylight period (Gilmanov et al., 2003, 2005). The detailed method to estimate the daytime ecosystem respiration using the light-response function analysis and the evaluation of the estimates of daytime respiration and tower-based GPP, was described by Gilmanov et al. (2003; 2005). Partitioning net $\mathrm{CO}_{2}$ fluxes into GPP and respiration based on light-response functions at the BREB and eddy covariance towers in the Northern Great Plains resulted in daytime respiration estimates are in good agreement with night- time measured respiration rates. GPP estimates of Northern Great Plains ecosystems based on these daytime respiration values also agree with existing GPP estimates for other ecosystems in the climatic gradient from shortgrass to tallgrass prairies.

Additional errors could originate from GPP model estimates. The variability in GPP at the site level could be influenced by precipitation and water content in soil. At the Miles City site, precipitation prior to July 2000 was lower than average, but abundant in June and July 2001. The intense drought in the spring and early summer of 2000 reduced soil water content and subsequently reduced total production by $20 \%$ to $40 \%$ (Heitschmidt et al., 2005). MODIS GPP was probably incapable of reflecting the influence of low water content in soil, which led to higher MODIS GPP than tower-based GPP (Fig. 4). Also, MODIS GPP had a later end of the growing season than towerbased GPP. In 2001, reduced water limitation on plant growth resulted in higher production. Yet this was not reflected by MODIS GPP, leading to a seasonal underestimate of GPP at the Miles City site in 2001. At the Lethbridge site, the drought in 2000 and 2001 (Flanagan et al., 2002; Flanagan \& Johnson, 2005 ) caused an early end of the growing season. Soil water was largely depleted by early July. The global MODIS GPP algorithm did not reflect the change in soil moisture and resulted in MODIS GPP having a prolonged growing season at the Lethbridge site.

Table 3

Agreement analysis of tower-based GPP and MODIS GPP

\begin{tabular}{|c|c|c|c|c|c|c|c|}
\hline Parameters & Lethbridge 2000 & Lethbridge 2001 & Fort Peck 2000 & Mandan 2000 & Mandan 2001 & Miles City 2000 & Miles City 2001 \\
\hline$n$ (observations) & 27 & 25 & 27 & 26 & 23 & 23 & 26 \\
\hline Mean of tower GPP $(\bar{T})$ & 1.27 & 1.51 & 1.84 & 1.96 & 2.49 & 1.35 & 1.61 \\
\hline Mean of MODIS GPP $(\bar{M})$ & 0.99 & 1.55 & 1.49 & 2.40 & 2.77 & 1.88 & 0.98 \\
\hline Difference of Mean $(\bar{M}-\bar{T})$ & -0.28 & 0.04 & -0.36 & 0.44 & 0.27 & 0.53 & -0.63 \\
\hline$r$ & 0.48 & 0.75 & 0.89 & 0.89 & 0.81 & 0.71 & 0.78 \\
\hline Regression $^{\mathrm{a}}$ slope & 0.29 & 0.37 & 0.73 & 0.95 & 0.98 & 0.66 & 0.41 \\
\hline Regression $^{\mathrm{a}}$ intercept & 0.63 & 0.99 & 0.13 & 0.53 & 0.32 & 0.99 & 0.30 \\
\hline$d$ & 0.62 & 0.76 & 0.91 & 0.92 & 0.88 & 0.79 & 0.67 \\
\hline $\operatorname{RMSE}\left(\mathrm{gCm}^{-2} \mathrm{~d}^{-1}\right)$ & 0.94 & 1.18 & 0.68 & 0.78 & 0.82 & 0.92 & 0.90 \\
\hline $\mathrm{MSE}_{\mathrm{S}} / \mathrm{MSE}(\%)$ & 67 & 79 & 52 & 33 & 11 & 48 & 88 \\
\hline $\mathrm{MSE}_{\mathrm{u}} / \mathrm{MSE}(\%)$ & 33 & 21 & 48 & 67 & 89 & 52 & 12 \\
\hline
\end{tabular}

a Tower-based GPP is the independent variable, and MODIS GPP is the dependent variable. 


\subsection{Cross-validation of PWR GPP at flux tower sites}

We compared PWR GPP with tower-based GPP using crossvalidation by withholding each site by year. The crossvalidation showed a good agreement $(r=0.82-0.98$ and $d=0.71-0.97$ ) between PWR GPP and tower-based GPP when withholding each site-year (Fig. 5 and Table 4). The systematic error accounted for the majority of the MSE when each of the site-years was withheld, except at Lethbridge and Miles City in 2001. The agreement was relatively lower when withholding the Mandan and Miles City sites than withholding other sites $(d=0.71$ for 2000 and $d=0.78$ for 2001 at the Mandan site, and $d=0.74$ for 2000 at Miles City). The results indicated that the Mandan and Miles City sites were influential sites for training the PWR model in this region. Total precipitation at the Mandan site for the 2000 and 2001 growing seasons was $406 \mathrm{~mm}$ and $437 \mathrm{~mm}$, respectively, while the highest total precipitation at the other sites was only $342 \mathrm{~mm}$. The Mandan site represented the climate extreme (wet site) in the training data sets. Precipitation at the Miles City site was lower than average before July 2000 (Heitschmidt et al., 2005). This site in 2000 represented a dry site in the training data sets.

Comparing Fig. 2 with Fig. 5, and Table 2 with Table 4, the agreement $(d)$ between tower-based GPP and PWR GPP decreased from 0.95 to 0.71 for 2000 and from 0.96 to 0.78 for 2001 by withholding the Mandan site, and the systematic error accounted for a higher proportion $(82 \%)$ of total error for both years. By withholding the Miles City site, the agreement $(d)$ also decreased from 0.98 to 0.74 for 2000 , and the systematic error accounted for a higher proportion $(90 \%)$ of total error. This further verifies that the Mandan and Miles City sites improved the robustness of the PWR model. It is important to use a wide variety of flux tower data sets as the training data for the empirical regional PWR model, as were observed in this large study area over a four-year period. Using different flux tower data to calibrate model parameters also seems important to the MODIS GPP model.

\subsection{Intercomparison of the PWR GPP and MODIS GPP maps}

The comparison in Section 4.1 helped us understand how GPP estimates compared at locations of known local carbon flux. In this section, we expanded this analysis to compare GPP spatial patterns based on PWR and MODIS model estimates for grasslands in the Northern Great Plains. The total GPP for the growing season based on the PWR and MODIS models showed consistently higher GPP in the east and south, and lower GPP in the west (Fig. 6). The match-paired t-tests indicate that the mean differences between PWR and MODIS GPP estimates are significant ( $p$-value $<0.05$ ) for both years. Over the growing season, the total PWR GPP moderately agreed with the total MODIS GPP $(r=0.71, d=0.79$ for 2000, and $r=0.77, d=0.80$ for 2001) (Fig. 7 and Table 5). The mean of MODIS GPP during the growing season was 353 and $375 \mathrm{~g} \mathrm{C} \mathrm{m}^{-2}$ for 2000 and 2001, respectively. The mean of PWR GPP during the growing season was 402 and $431 \mathrm{~g} \mathrm{C} \mathrm{m}^{-2}$ for the two years, respectively.
MODIS GPP was $49 \mathrm{~g} \mathrm{C} \mathrm{m}^{-2}$ lower than PWR GPP on average, with an RMSE of $88 \mathrm{~g} \mathrm{C} \mathrm{m}^{-2}$ in 2000 , and $56 \mathrm{~g} \mathrm{C} \mathrm{m}^{-2}$ lower than PWR GPP on average, with an RMSE of $88 \mathrm{~g} \mathrm{C} \mathrm{m}^{-2}$ in 2001. The seasonal total MODIS GPP is lower than the seasonal total PWR GPP, which is consistent with the comparison at the flux tower sites (Fig. 4). From Fig. 4, the MODIS GPP underestimated GPP four of seven site-years (Fort Peck 2000, Miles City 2001, Lethbridge 2000, and Lethbridge 2001), but overestimated only one time at Miles City 2000.
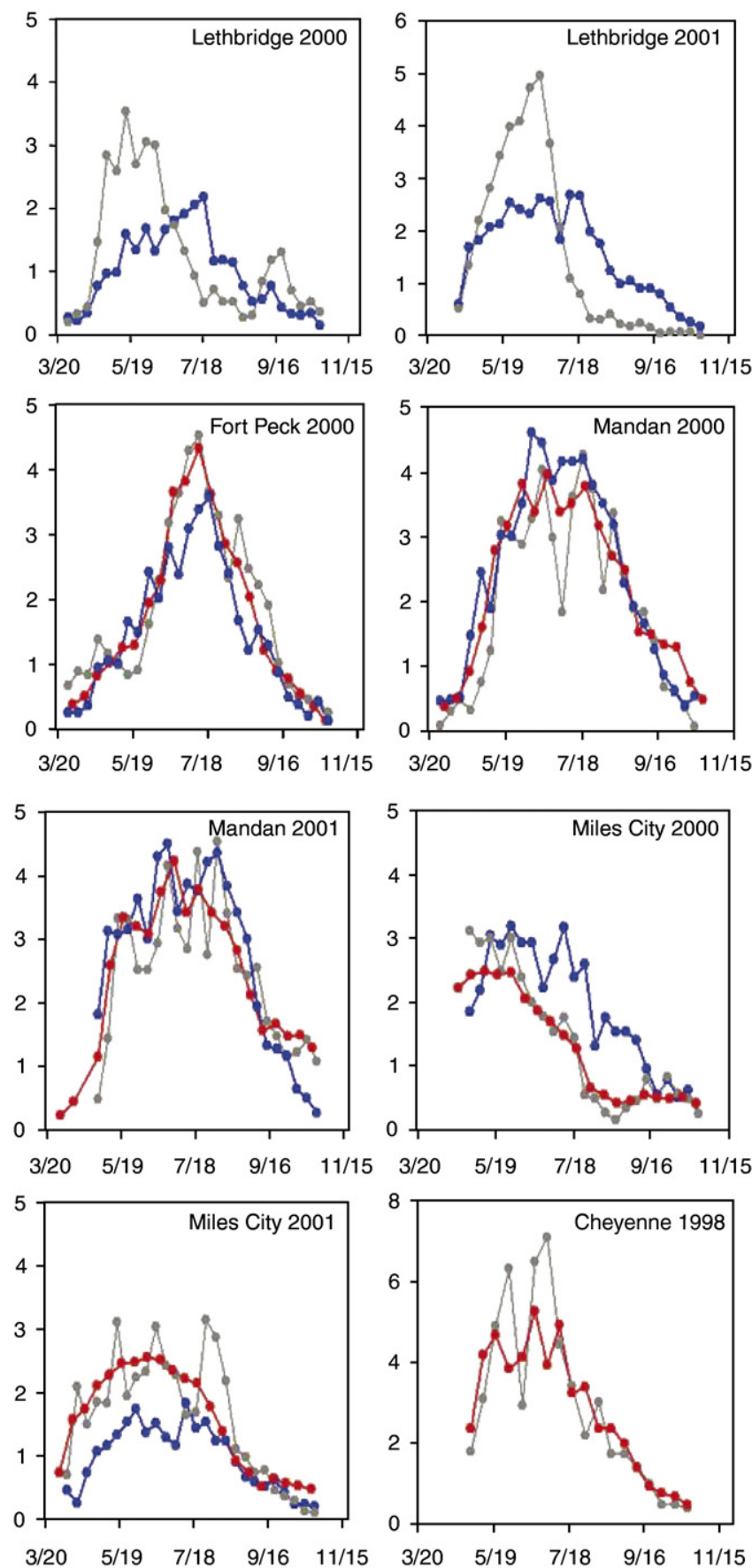

$\bullet$ Tower GPP $\bullet$ PWR GPP

$\longrightarrow$ MODIS GPP

Fig. 4. Seasonal dynamics of GPP during the growing seasons at flux towers. 

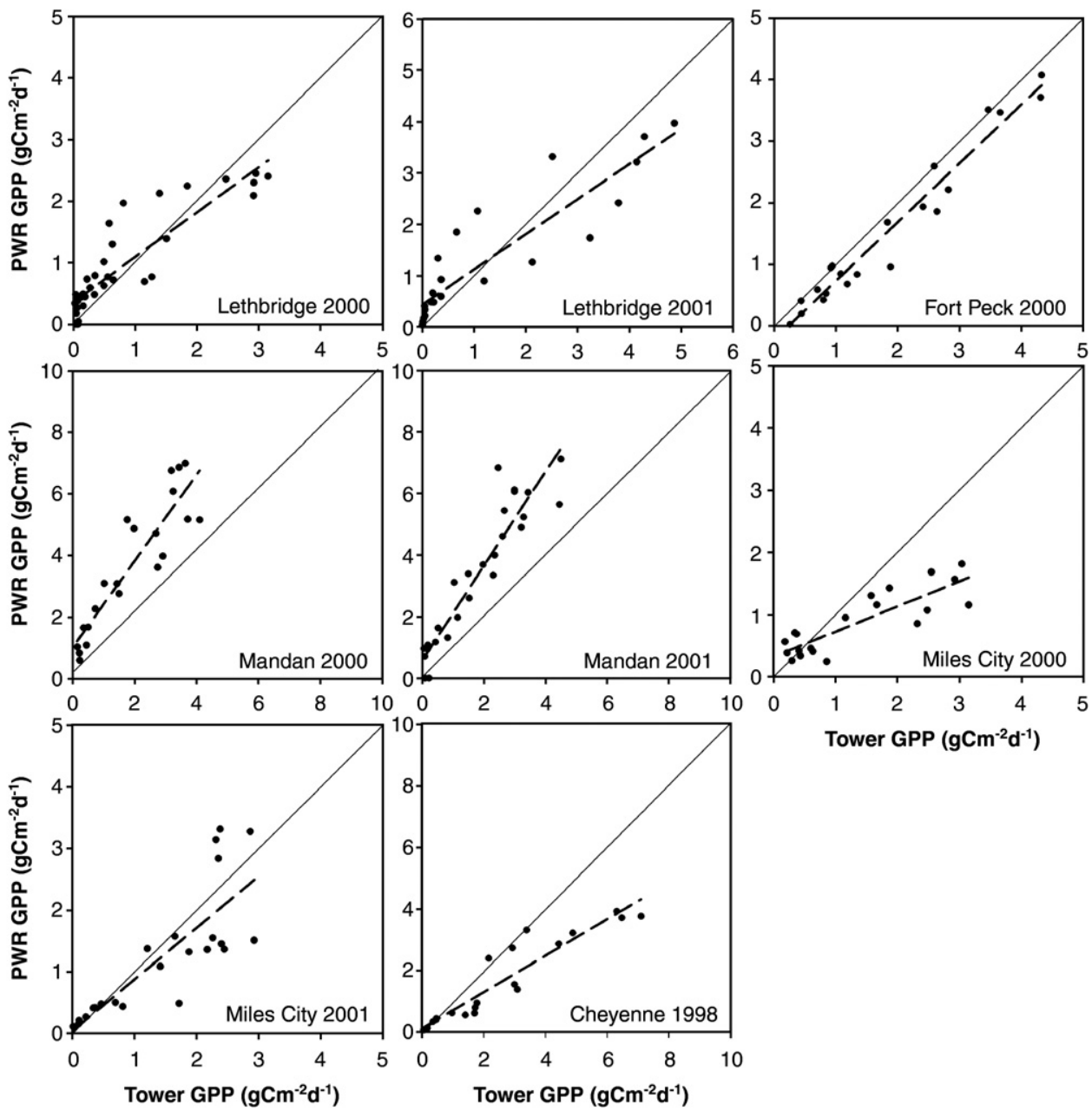

Tower GPP $\left(\mathrm{gCm}^{-2} \mathrm{~d}^{-1}\right)$

Fig. 5. Cross-validation by withholding each site in each year, and comparison between tower-based GPP and PWR GPP at the held-out flux tower (10-day interval). The dashed line represents the regression line. The solid line represents the 1:1 line.

\subsection{Ecosystem characteristics contributing to GPP difference patterns}

We calculated difference maps of total GPP during the growing season between MODIS and PWR model estimates (Fig. 8). PWR GPP was lower in the southeast and higher in the west and south than MODIS GPP. The GPP difference patterns reflect the inconsistency of estimates from the two GPP models, which may be attributed to differences in the underlying model structure, model algorithms, and model inputs. An inspection of the two model algorithms suggests that several variables might contribute to GPP difference patterns.

Table 4

Cross-validation of PWR GPP by withholding each site in each year

\begin{tabular}{|c|c|c|c|c|c|c|c|c|}
\hline \multirow[t]{2}{*}{ Parameters } & \multicolumn{8}{|c|}{ Withholding sites } \\
\hline & $\begin{array}{l}\text { Lethbridge } \\
2000\end{array}$ & $\begin{array}{l}\text { Lethbridge } \\
2001\end{array}$ & $\begin{array}{l}\text { Fort Peck } \\
2000\end{array}$ & $\begin{array}{l}\text { Mandan } \\
2000\end{array}$ & $\begin{array}{l}\text { Mandan } \\
2001\end{array}$ & $\begin{array}{l}\text { Miles City } \\
2000\end{array}$ & $\begin{array}{l}\text { Miles City } \\
2001\end{array}$ & $\begin{array}{l}\text { Cheyenne } \\
1998\end{array}$ \\
\hline$n$ (observations) & 35 & 23 & 21 & 21 & 27 & 20 & 24 & 21 \\
\hline Mean of tower GPP $(\bar{T})$ & 0.81 & 1.29 & 1.85 & 1.90 & 1.74 & 1.35 & 1.38 & 2.52 \\
\hline Mean of PWR GPP $(\bar{P})$ & 0.95 & 1.32 & 1.55 & 3.69 & 3.25 & 0.87 & 1.20 & 1.60 \\
\hline Difference of mean $(\bar{P}-\bar{T})$ & 0.14 & 0.03 & -0.31 & 1.79 & 1.51 & -0.48 & -0.18 & -0.92 \\
\hline$r$ & 0.89 & 0.90 & 0.98 & 0.91 & 0.94 & 0.85 & 0.82 & 0.94 \\
\hline Regression $^{\mathrm{a}}$ slope & 0.73 & 0.68 & 0.95 & 1.39 & 1.53 & 0.40 & 0.84 & 0.59 \\
\hline Regression ${ }^{\mathrm{a}}$ intercept & 0.36 & 0.44 & -0.22 & 1.04 & 0.59 & 0.33 & 0.04 & 0.11 \\
\hline$d$ & 0.93 & 0.93 & 0.97 & 0.71 & 0.78 & 0.74 & 0.89 & 0.86 \\
\hline $\operatorname{RMSE}\left(\mathrm{gCm}^{-2} \mathrm{~d}^{-1}\right)$ & 0.47 & 0.74 & 0.41 & 2.06 & 1.86 & 0.82 & 0.63 & 1.36 \\
\hline $\mathrm{MSE}_{\mathrm{S}} / \mathrm{MSE}(\%)$ & 41 & 48 & 59 & 82 & 82 & 90 & 15 & 88 \\
\hline $\mathrm{MSE}_{\mathrm{u}} / \mathrm{MSE}(\%)$ & 59 & 52 & 41 & 18 & 18 & 10 & 85 & 12 \\
\hline
\end{tabular}

a Tower-based GPP is the independent variable, and PWR GPP is the dependent variable. 


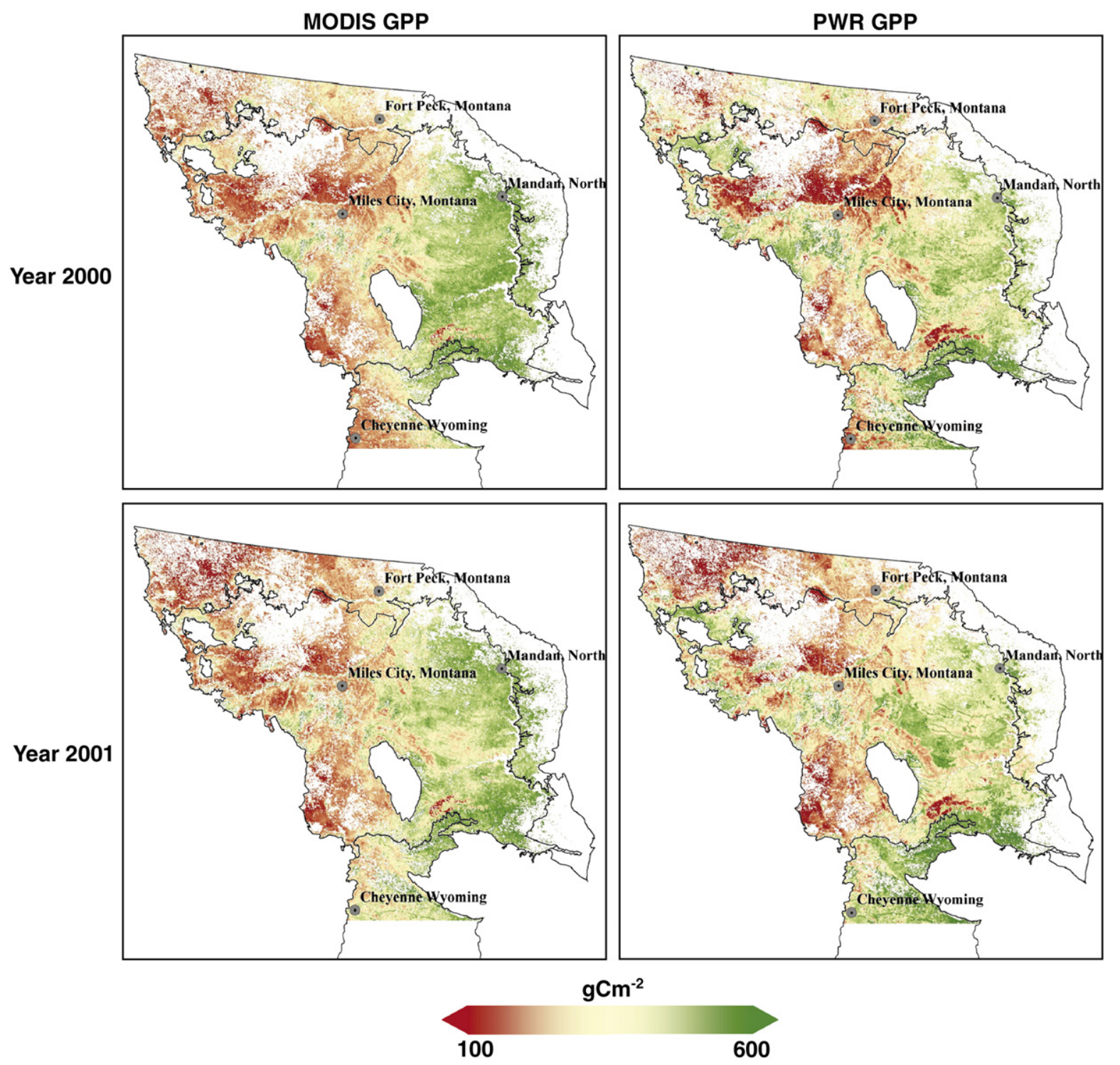

Fig. 6. Total GPP during the growing season in the Northern Great Plains based on MODIS and PWR models.

A preliminary analysis of the frequency of use and the relevance in the regression models (a method used in Wylie et al., 2003) revealed that the variables from the PWR model that had greater influence on the GPP differences were meteorological data (summer precipitation and temperature), phenological metrics (SOST and SOSN), and proportion of $\mathrm{C}_{4}$ grasses. Precipitation is a critical factor affecting production of rangeland ecosystems (Heitschmidt et al., 1999). Smart et al. (2005) found that precipitation from April to June is an important determinant of grassland production in the Northern Great Plains. Its significance in explaining model differences implies that precipitation was not adequately captured by one of the models. Considering that MODIS GPP had lagged initiation and cessation relative to tower-based GPP at Lethbridge and prolonged late seasonal GPP at Miles City in 2000 (Fig. 4), we suspect the differences were largely attributed to errors in MODIS GPP estimates. Comparing with the input for PWR GPP model, the meteorological data for MODIS GPP model have a coarser resolution that may introduce substantial error into MODIS GPP estimates (Zhao \& Running, 2006).

Other ecosystem characteristics excluded in the inputs of the PWR and MODIS models might contribute more toward
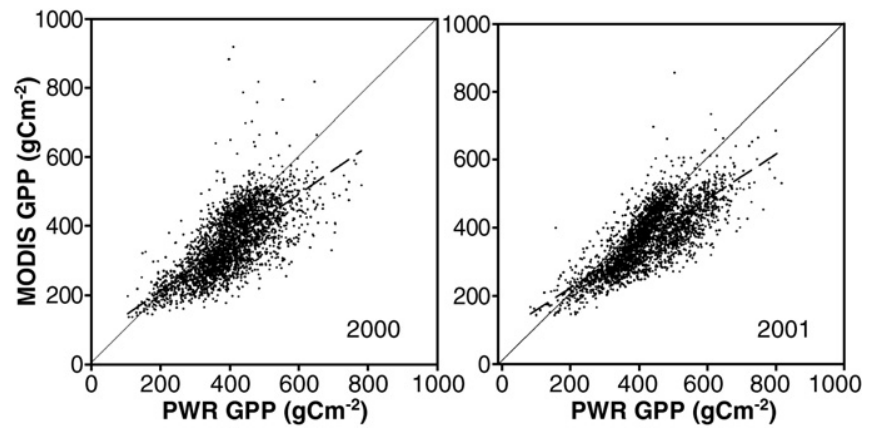

Fig. 7. Scatter plots of MODIS GPP versus PWR GPP for 2000 and 2001. The dashed line represents the regression line. The solid line represents the 1:1 line. 
Table 5

Agreement analysis of PWR GPP and MODIS GPP

\begin{tabular}{|c|c|c|}
\hline Parameters & Year 2000 & Year 2001 \\
\hline$n$ (observations) & 2951 & 2951 \\
\hline Mean of PWR GPP $(\bar{P})$ & 402 & 431 \\
\hline Mean of MODIS GPP $(\bar{M})$ & 353 & 375 \\
\hline Difference of mean $(\bar{M}-\bar{P})$ & -49 & -56 \\
\hline$r$ & 0.71 & 0.77 \\
\hline Regression $^{\mathrm{a}}$ slope & 0.70 & 0.65 \\
\hline Regression $^{\mathrm{a}}$ intercept & 72.28 & 93.73 \\
\hline$d$ & 0.79 & 0.80 \\
\hline $\operatorname{RMSE}\left(\mathrm{gCm}^{-2}\right)$ & 88 & 88 \\
\hline
\end{tabular}

a PWR GPP is the independent variable and MODIS GPP is the dependent variable.

explaining the GPP difference patterns, including percentage of clay, water holding capacity, and percentage of crops. In the decision tree analysis, we focused on these three variables and the proportion of $\mathrm{C}_{4}$ grasses (denoted as $\mathrm{C}_{4}$ ). GPP difference patterns (MODIS GPP minus PWR GPP, $\mathrm{g} \mathrm{C} \mathrm{m}^{-2}$ ) were classified into five categories: 1) less than $-100,2$ ) between -100 and $-50,3)$ between -50 and 50,4$)$ between 50 and 100 , and 5) greater than 100 . The $1 \mathrm{st}, 3 \mathrm{rd}$, and 5 th categories were studied, and the intermediate categories (2 and 4) were excluded. We implemented the decision tree algorithm with the four input variables (Fig. 9) and one output variable (Fig. 8) represented by the 1st, 3rd, and 5th GPP difference categories defined above. Five hundred random pixels were generated for each of the three categories from the difference map as training samples. The decision tree model was then developed from the combined 1500 training samples.

Two decision trees were formulated from the four spatial variables (Fig. 9) and were used to predict GPP difference patterns for 2000 and 2001, separately. The training accuracy for modeling the three categories of GPP differences was $77.3 \%$ for 2000 and $82.5 \%$ for 2001 . Three of the four spatial input variables were derived from the STATSGO database. The coarse STATSGO data does not correspond to the detail of the $1-\mathrm{km}$ resolution data. Therefore, we did not expect high (>90\%) accuracies from the decision tree predictions.

\subsubsection{Spatial relationships between GPP difference patterns and influential variables for 2000}

The interpretation of the decision tree for 2000 showed how GPP difference patterns might be explained by the four variables. The decision tree for 2000 had 10 terminal nodes (Fig. 10), with 3 terminal nodes classified as areas where PWR GPP was much higher than MODIS GPP (1st category), and 2 terminal nodes classified as areas where PWR GPP was much lower than MODIS GPP (5th category). The first split was at the WHC value of 8 . The proportion of $\mathrm{C}_{4}$ grasses was the next dominant splitting variable. $\mathrm{C}_{4}$ and WHC separated two terminal nodes, $1 \mathrm{a}$ and $5 \mathrm{a}$. Further separation at nodes $1 \mathrm{~b}, 1 \mathrm{c}$, and $5 \mathrm{~b}$ was dominated by $\mathrm{C}_{4}$, Crop, and Clay. The relative importance of variables influencing the difference pattern was inferred by the percentage of utilization of each spatial variable in the decision tree (Table 6). For 2000, the variable with the highest influence was $\mathrm{C}_{4}$, with $\mathrm{WHC}$ and Crop as the second and third most influential variables. Clay was the least influential variable.

The decision tree rules (Fig. 10) were applied to classify the entire study area. For 2000, five classes were identified in training rules and mapped for the area (Fig. 11), including three classes (1a, 1b, and 1c) where PWR was much higher than MODIS GPP (1st category), and two classes (5a and 5b) where PWR was much lower than MODIS GPP (5th category). The higher WHC and lower $\mathrm{C}_{4}$ conditions dominated the northwestern region where PWR GPP was much higher than MODIS GPP, whereas higher WHC and higher $\mathrm{C}_{4}$ conditions controlled the southern region.

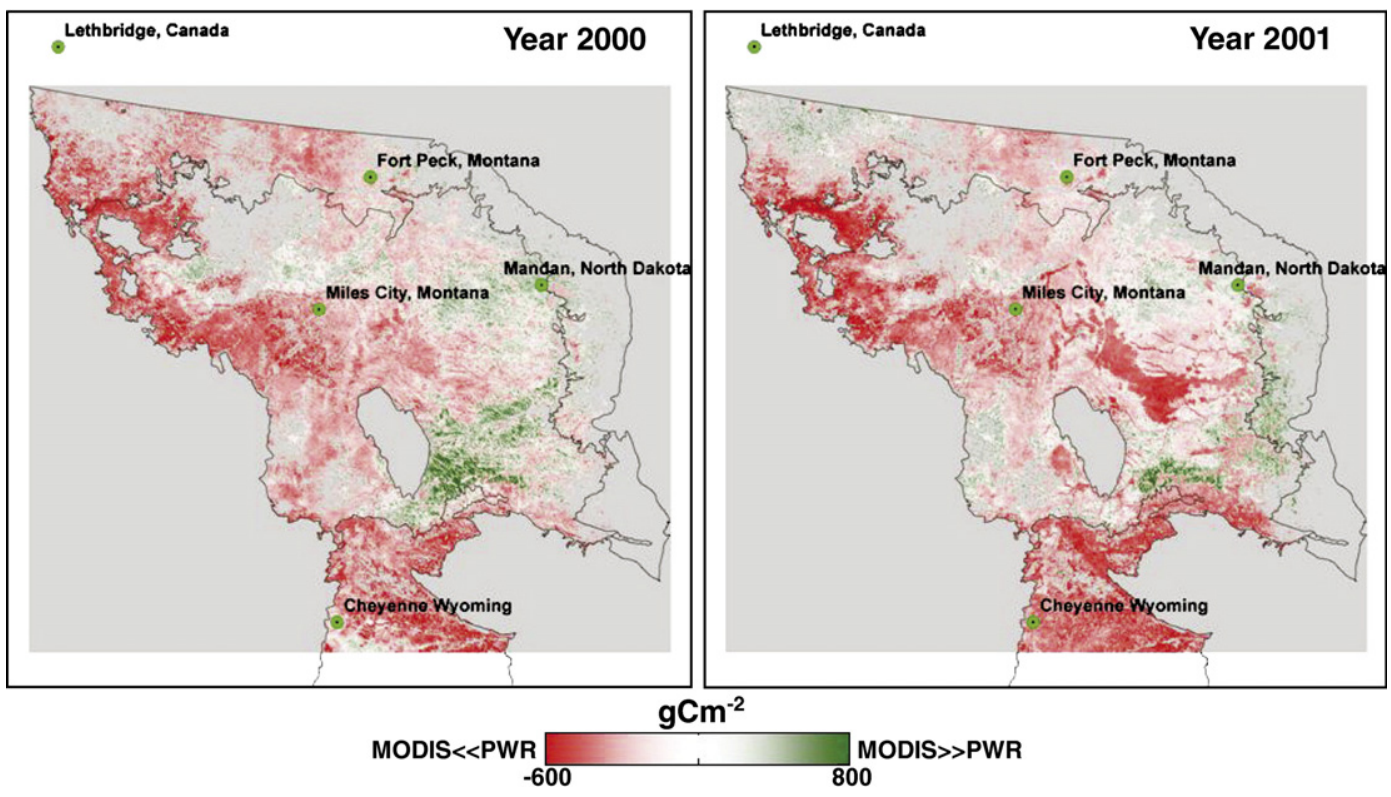

Fig. 8. Seasonal total GPP difference in the Northern Great Plains between MODIS and PWR GPP (MODIS GPP minus PWR GPP). 

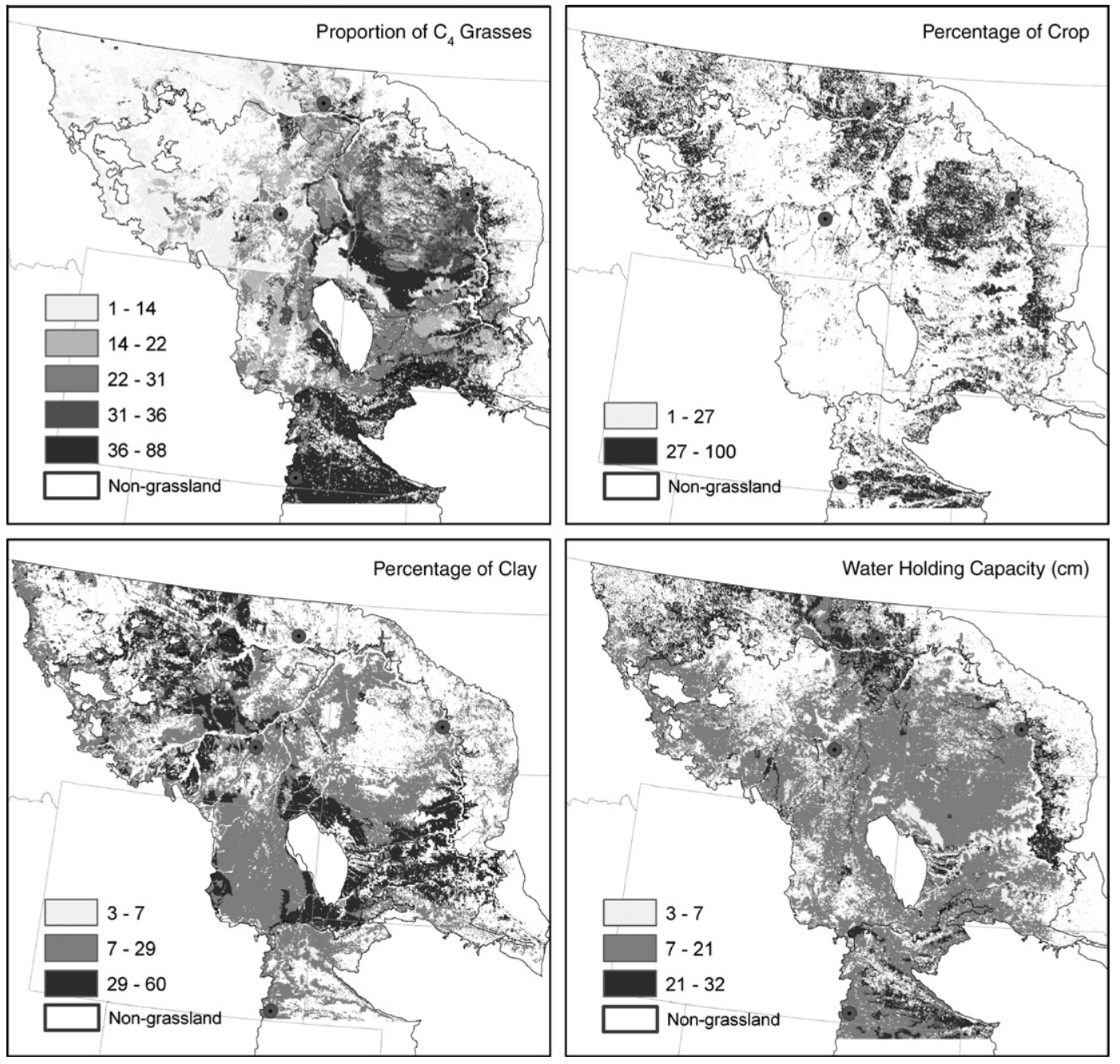

Fig. 9. Four environmental variables used in the decision tree analysis.

4.4.2. Spatial relationships between GPP difference patterns and influential variables for 2001

The interpretation of the decision tree (Fig. 12) for 2001 showed that $\mathrm{C}_{4}$ was the most important variable. The final simplified decision tree for 2001 had 10 terminal nodes, with two terminal nodes (1a and $1 \mathrm{~b}$ ) classified as areas where PWR GPP was much higher than MODIS GPP, which were separated by $\mathrm{C}_{4}$ and WHC. $\mathrm{C}_{4}$, Crop, and Clay provided another

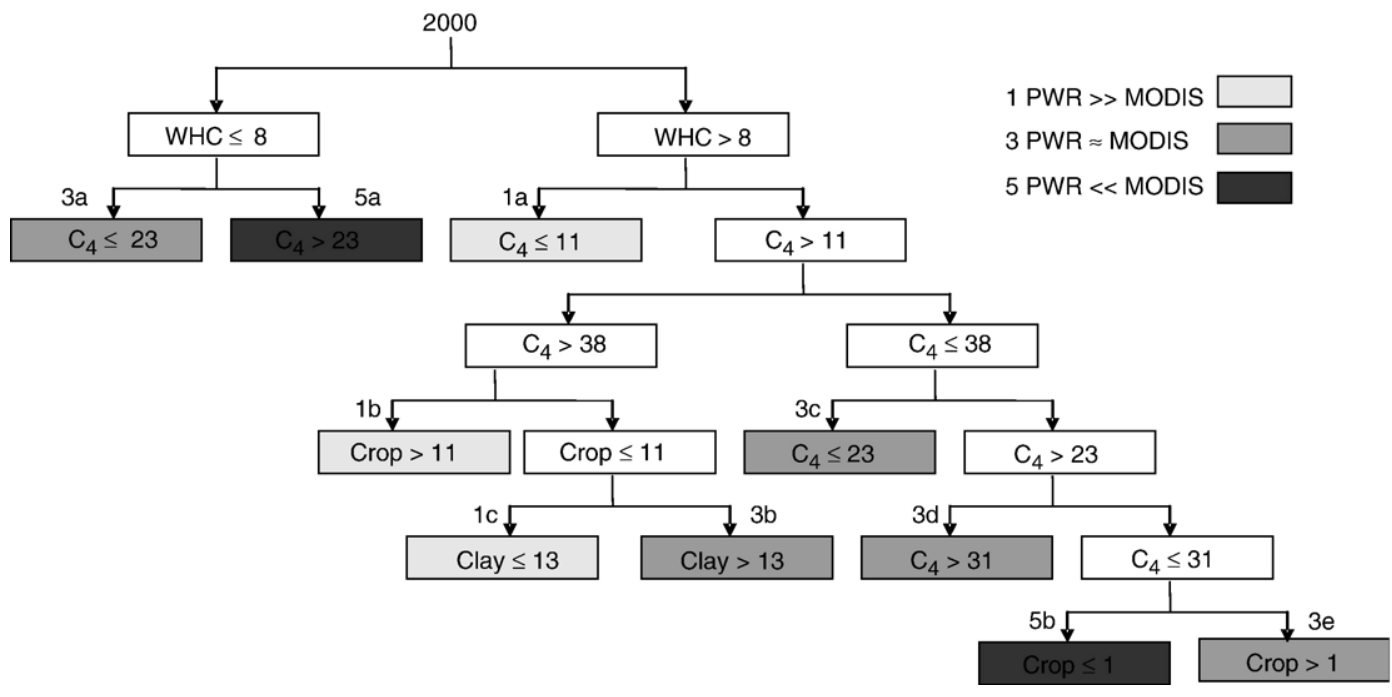

Fig. 10. Decision tree based on four variables for 2000 . 
Table 6

Rank of the importance of variables in the decision tree for 2000

\begin{tabular}{|c|c|c|c|c|}
\hline \multirow[t]{2}{*}{ Variables } & \multicolumn{3}{|c|}{ Utilization for classification (\%) } & \multirow{2}{*}{$\begin{array}{l}\text { Total } \\
\text { utilization } \\
\text { for } \\
\text { classification } \\
(\%)\end{array}$} \\
\hline & $\begin{array}{l}\text { PWR GPP >> } \\
\text { MODIS GPP }\end{array}$ & $\begin{array}{l}\text { PWR GPP } \approx \\
\text { MODIS GPP }\end{array}$ & $\begin{array}{l}\text { PWR GPP }<< \\
\text { MODIS GPP }\end{array}$ & \\
\hline $\mathrm{C}_{4}$ & 48 & 66 & 60 & 60 \\
\hline WHC & 33 & 24 & 30 & 28 \\
\hline Crop & 14 & 7 & 10 & 10 \\
\hline Clay & 5 & 3 & 0 & 2 \\
\hline
\end{tabular}

separation for the other two terminal nodes ( $5 a$ and $5 b)$, which were classified as areas where PWR GPP was much lower than MODIS GPP. The rank of the four influential variables indicated that $\mathrm{C}_{4}$, Clay, Crop, and $\mathrm{WHC}$ had the strongest to the weakest influences on the difference patterns for 2001 (Table 7).

The decision tree rules were applied to map the entire study area for 2001. Four classes were identified in the training rules (Fig. 13), including two classes (1a and 1b) where PWR GPP was much higher than MODIS GPP, and two classes (5a and 5b) where PWR GPP was much lower than MODIS GPP. The classes where PWR GPP was much higher than MODIS GPP occurred at lower $\mathrm{C}_{4}$ with higher WHC in the northwestern grassland or higher $\mathrm{C}_{4}$ in the southern, southeastern, and central parts of the study area. The classes where PWR GPP was much lower than MODIS GPP occurred in the central and southeastern parts of the study area, showing a spatial distribution similar to 2000. These areas contained mixed $\mathrm{C}_{3} /$ $\mathrm{C}_{4}$ grasses with the proportion of $\mathrm{C}_{4}$ grasses ranging from $20 \%$ to $40 \%$, which was consistent with the decision tree model for 2000 .

\subsubsection{Influence of ecosystem characteristics on the GPP difference maps}

The decision tree analysis showed the relative importance and hierarchical relationship of ecosystem characteristics on GPP difference patterns between PWR GPP and MODIS GPP in the Northern Great Plains. The results for both years showed that the GPP difference patterns have the highest sensitivity to $\mathrm{C}_{4}$ grasses. Water holding capacity and percentage of clay are two correlated soil variables for which the ranks were interchanged across the two years. Percentage of cropland follows these in importance. The dominant separation of the GPP difference patterns based on $\mathrm{C}_{4}$ and soil data may indicate poor characterization of the two variables in the global MODIS GPP model. The regional PWR model responds closely to local ecosystem and environmental change, but the global MODIS GPP model is not sensitive to regional ecosystem change and extreme soil moisture condition.

4.4.3.1. Proportions of $C_{4}$ grasses. $\mathrm{C}_{3}$ and $\mathrm{C}_{4}$ grasses are two major grass functional types with different environmental requirements, which are distinguished by the photosynthetic pathway. $\mathrm{C}_{4}$ species, in general, dominate areas that are warmer and with less available water than $\mathrm{C}_{3}$ grass species. In the Northern Great Plains, $\mathrm{C}_{4}$ species account for a higher proportion of production in the south than in the north (Tieszen et al., 1997). The PWR model used the proportion of $\mathrm{C}_{4}$ species

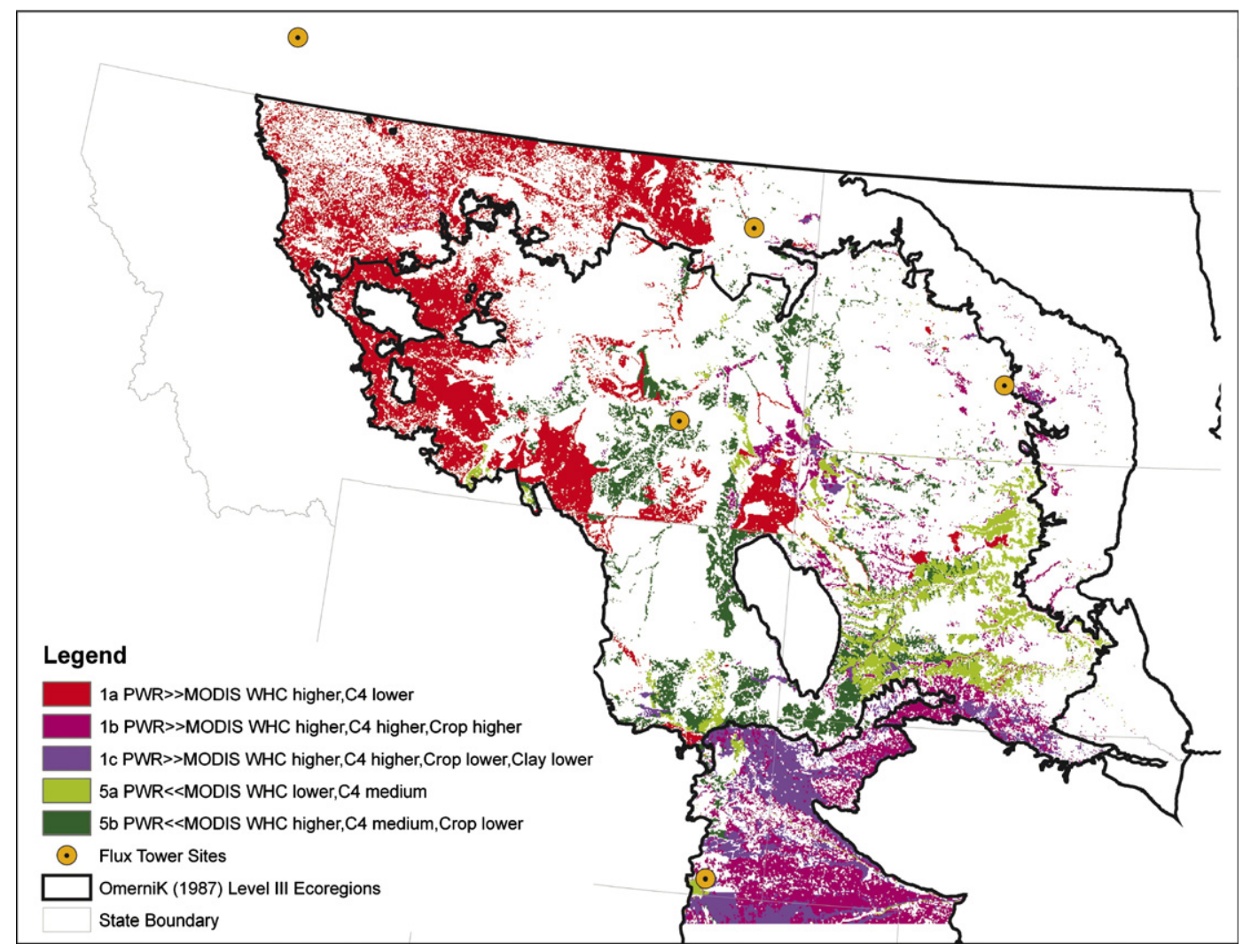

Fig. 11. Difference patterns represented by the four variables from the decision tree rules for 2000 . 


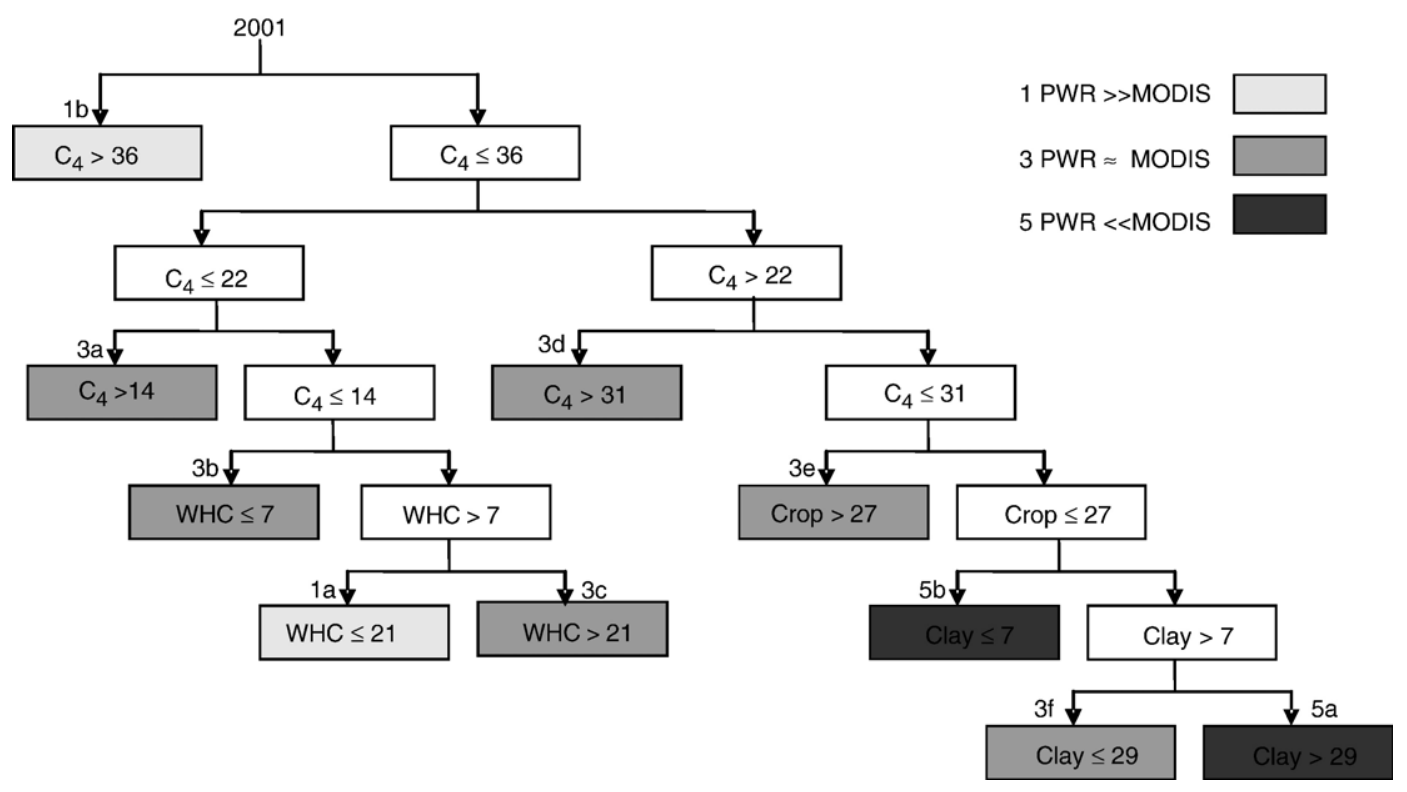

Fig. 12. Decision tree based on four variables for 2001.

as an independent variable in the regression training algorithm. $\mathrm{C}_{3}$ and $\mathrm{C}_{4}$ grasses are not distinguished in the MODIS algorithm (e.g., the BPLUT from Heinsch et al., 2003), thus ecosystem responses of $\mathrm{C}_{3}$ and $\mathrm{C}_{4}$ grasses are probably not captured by the MODIS GPP model. Under the warmer and drier condition, $\mathrm{C}_{4}$ grasses will produce higher production than $\mathrm{C}_{3}$ grasses because $\mathrm{C}_{4}$ grasses have higher water use efficiency. Yet, higher VPD in the MODIS model will probably reduce the GPP estimates without considering $\mathrm{C}_{4}$ grasses. As we have seen from Figs. 11 and 13, MODIS GPP was much lower than PWR GPP in both years in the southern area where is dominated by the higher proportion of $\mathrm{C}_{4}$ grasses.

\subsubsection{Soils (water holding capacity and percentage of clay).}

Soil moisture and soil texture control vegetation growth (Churkina et al., 1999). Williams et al. (1997) reported that soil water availability is a stronger constraint on GPP than vapor pressure deficit. Neither the PWR model nor the MODIS model takes into account soil water availability and percentage of clay. Summer water stress is particularly severe during the late summer in the Northern Great Plains grasslands. Water stress is driven by VPD in the MODIS GPP model and the LUE model

Table 7

Rank of the importance of variables in the decision tree for 2001

\begin{tabular}{lllll}
\hline Variables & \multicolumn{2}{l}{ Utilization for classification $(\%)$} & $\begin{array}{l}\text { Total } \\
\text { utilization }\end{array}$ \\
\cline { 2 - 5 } & $\begin{array}{l}\text { PWR GPP }>> \\
\text { MODIS GPP }\end{array}$ & $\begin{array}{l}\text { PWR GPP } \approx \\
\text { MODIS GPP }\end{array}$ & $\begin{array}{l}\text { PWR GPP }<< \\
\text { MODIS GPP }\end{array}$ & $\begin{array}{l}\text { for } \\
\text { classification } \\
(\%)\end{array}$ \\
\hline $\mathrm{C}_{4}$ & 70 & 78 & 56 & 66 \\
Clay & 0 & 6 & 26 & 14 \\
Crop & 0 & 6 & 19 & 10 \\
WHC & 30 & 9 & 0 & 10 \\
\hline
\end{tabular}

does not simulate the water balance, which limits its ability to detect drought stress (Turner et al., 2005). The $1.00^{\circ} \times 1.25^{\circ}$ meteorological data sets used in the MODIS GPP model may underestimate local VPD under the dry conditions, resulting in local overestimation of MODIS GPP (Heinsch et al., 2006). The additional parameter is required to characterize soil water availability in the MODIS model and thus account for deficiencies in VPD (Plummer, 2006). Variations in precipitation have less influence on vegetation vigor in areas where soil has a higher water holding capacity. This suggests that the PWR GPP normally would be much higher than MODIS GPP when soil water storage (WHC or Clay) is high. In this situation, sufficient water is stored and the vegetation response to lack of precipitation is somewhat buffered. MODIS GPP may also ignore the soil impact on vegetation production.

4.4.3.3. Percentage of cropland. The MODIS GPP model was designed for global land surface monitoring and may have limitations at the regional scale. For these ecoregions, MODIS GPP estimates relied on MODIS land cover data that may not differentiate sub-pixel cropland components in each $1-\mathrm{km}^{2}$ grassland pixel. The percentage of sub-pixel cropland derived from the NLCD is unevenly distributed in the Northern Great Plains grasslands with a high proportion in the north and south (Fig. 9). MODIS land cover products, however, classified these regions as grassland, which may be a reason for the disparity between PWR GPP and MODIS GPP. Bradford et al. (2005) found a positive relationship between crop intensity and production. In these regions, the MODIS model may underestimate GPP, resulting in lower MODIS GPP than PWR GPP. In addition, crops can be classified into $\mathrm{C}_{3}$ and $\mathrm{C}_{4}$ types in this region. The possible incorporation of cropland sub-pixels into the input of the MODIS model may cause even more complicated results. Therefore, distinguishing $\mathrm{C}_{3}$ from $\mathrm{C}_{4}$ plant types for Northern Great Plains croplands might provide 


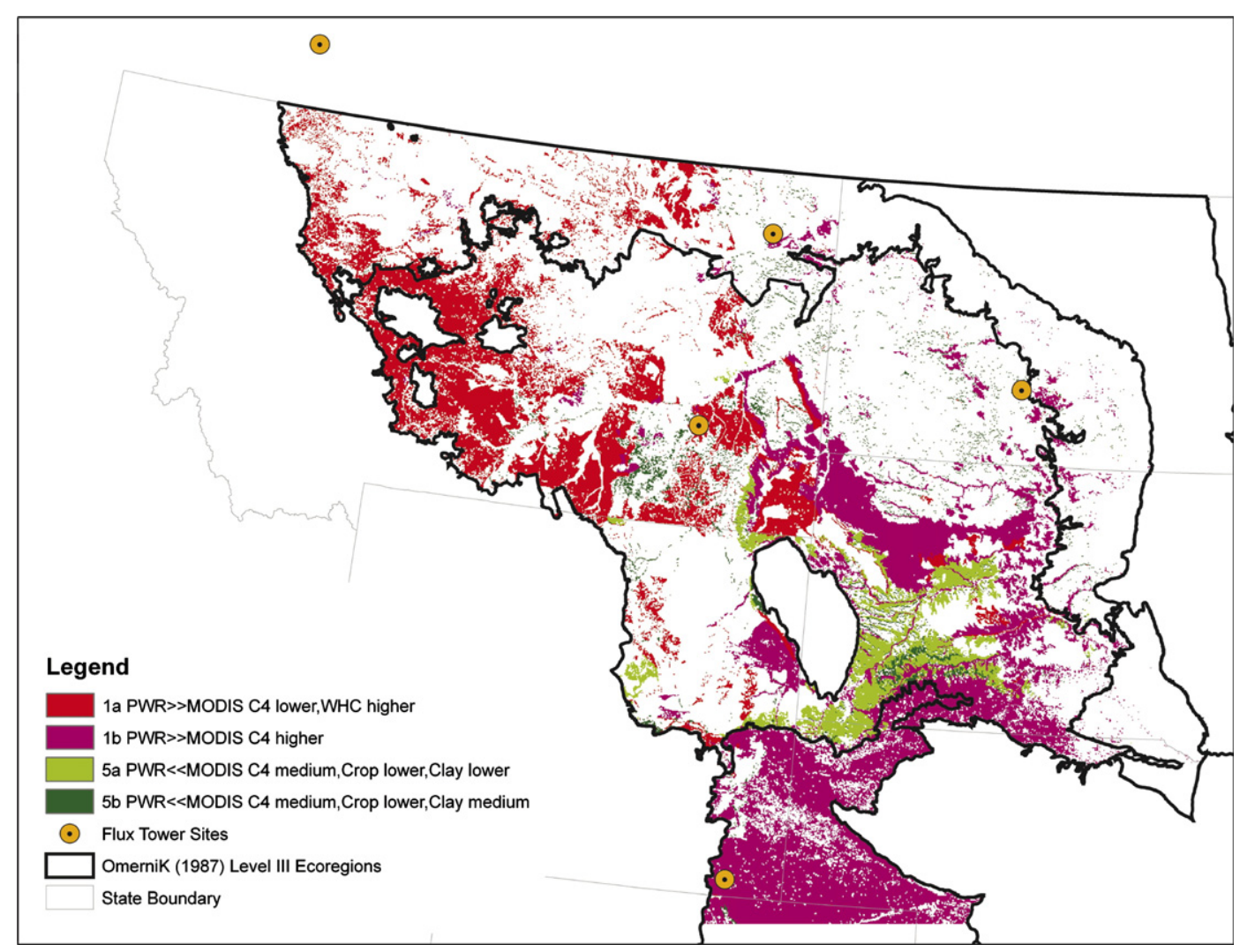

Fig. 13. Difference patterns represented by the four variables from the decision tree rules for 2001.

further explanation of the GPP differences generated by the PWR and MODIS models.

\section{Conclusions}

Cross-validation in this study indicated the robustness of the PWR model for predicting grassland GPP in the Northern Great Plains. The global MODIS GPP model may have three limitations in predicting GPP for grassland in the Northern Great Plains: 1) responding to the soil water content in dry years, 2) differentiating $\mathrm{C}_{3}$ and $\mathrm{C}_{4}$ grasses, and 3) separating mixed cropland/grassland pixels. The relationships found in this study may be useful for exploring the influence of soil and ecosystem characteristics on the modeling of grassland production. The results reinforce the perception that soils data, $\mathrm{C}_{3} / \mathrm{C}_{4}$ grasses, and land cover data have strong impact on the prediction of GPP in grassland ecosystems. The impact of ecosystem characteristics on GPP estimates from different models cannot be easily assessed because their interactions vary through space and time. To reduce the uncertainty from input data sets, more work is needed to evaluate the PWR model in other grassland ecoregions and other ecosystems to examine the robustness of the PWR model and its stability in different environmental and biophysical conditions.

\section{Acknowledgements}

This research was supported by the U.S. Geological Survey (USGS) Earth Surface Dynamics, Land Remote Sensing, and
Geographic Analysis and Monitoring Programs. The flux towers are part of the AmeriFlux network and the AgriFlux network. We acknowledge Albert Frank, Marshall Haferkamp, Tilden Meyers, Larry Flanagan, and Jack Morgan for providing the flux tower data. We would also like to thank Norman Bliss, Zhengxi Tan, and Chris Wright for valuable comments and suggestions on the manuscript.

\section{References}

Amthor, J. S., Chen, J. M., Clein, J. S., Frolking, S. E., Goulden, M. L., Grant, R. F., et al. (2001). Boreal forest $\mathrm{CO}_{2}$ exchange and evapotranspiration predicted by nine ecosystem process models: Intermodel comparisons and relationships to field measurements. Journal of Geophysical Research: Atmospheres, 106 (D24), 33623-33648.

Angell, R. F., Svejcar, T., Bates, J., Saliendra, N. Z., \& Johnson, D. A. (2001). Bowen ratio and closed chamber carbon dioxide flux measurements over sagebrush steppe vegetation. Agricultural and Forest Meteorology, 108(2), 153-161.

Baldocchi, D., Falge, E., Gu, L., Olson, R., Hollinger, D., Running, S., et al. (2001). FLUXNET: A new tool to study the temporal and spatial variability of ecosystem-scale carbon dioxide, water vapor, and energy flux densities. Bulletin of the American Meteorological Society, 82(11), 2415-2434.

Bradford, J. B., Lauenroth, W. K., \& Burke, I. C. (2005). The impact of cropping on primary production in the U.S. Great Plains. Ecology, 86(7), 1863-1872.

Breiman, L., Friedman, J. H., Olshen, R. A., \& Stone, C. J. (1984). Classification and regression trees. California: Wadsworth.

Burke, I. C., Lauenroth, W. K., \& Milchunas, D. G. (1997). Biogeochemistry of managed grassland in central North America. In E. A. Paul, K. Paustian, E. T. Elliot, \& C. V. Cole (Eds.), Soil organic matter in temperate agroecosystems (pp. 85-102). Florida: CRC Press.

Churkina, G., Running, S. W., Schloss, A. L., \& the participants of the Potsdam NPP model intercomparison. (1999). Comparing global models of terrestrial 
net primary productivity (NPP): The importance of water availability. Global Change Biology, 5(Suppl. 1), 46-55.

Connor, R., Seidl, A., Van Tassell, L., \& Wilkins, N. (2001). United States grasslands and related resources: An economic and biological trends assessment. URL. http://landinfo.tamu.edu/presentations/grasslands.cfm

Emmerich, W. E. (2003). Carbon dioxide fluxes in a semiarid environment with high carbonate soils. Agricultural and Forest Meteorology, 116(1-2), 91-102.

Eswaran, H., Van Den Berg, E., \& Reich, P. (1993). Organic carbon in soils of the world. Soil Science Society of America Journal, 57(1), 192-194.

Flanagan, L. B., \& Johnson, B. G. (2005). Interacting effects of temperature, soil moisture and plant biomass production on ecosystem respiration in a northern temperate grassland. Agricultural and Forest Meteorology, 130(3-4), 237-253.

Flanagan, L. B., Wever, L. A., \& Carlson, P. J. (2002). Seasonal and interannual variation in carbon dioxide exchange and carbon balance in a northern temperate grassland. Global Change Biology, 8(7), 599-615.

Frank, A. B. (2004). Six years of CO2 flux measurements for a moderately grazed mixed-grass prairie. Environmental Management, 33(Suppl. 1), S426-S431.

Gilmanov, T. G., Johnson, D. A., Saliendra, N. Z., Akshalov, K., \& Wylie, B. K. (2004). Gross primary productivity of the true steppe in Central Asia in relation to NDVI: Scaling up $\mathrm{CO}_{2}$ fluxes. Environmental Management, 33 (Suppl. 1), S492-S508.

Gilmanov, T. G., Tieszen, L. L., Wylie, B. K., Flanagan, L. B., Frank, A. B., Haferkamp, M. R., et al. (2005). Integration of $\mathrm{CO}_{2}$ flux and remotely sensed data for primary production and ecosystem respiration analyses in the Northern Great Plains: Potential for quantitative spatial extrapolation. Global Ecology and Biogeography, 14(3), 271-292.

Gilmanov, T. G., Verma, S. B., Sims, P. L., Meyers, T. P., Bradford, J. A., Burba, G. G., et al. (2003). Gross primary production and light response parameters of four Southern Plains ecosystems estimated using long-term $\mathrm{CO}_{2}$-flux tower measurements. Global Biogeochemical Cycles, 17(2), 1071. doi:10.1029/2002GB002023.

Goulden, M. L., Munger, W. J., Fan, S., Daube, B. C., \& Wofsy, S. C. (1996). Measurements of carbon sequestration by long-term eddy covariance: Methods and a critical evaluation of accuracy. Global Change Biology, 2(3), 169-182.

Heinsch, F. A., Reeves, M., Votava, P., Kang, S., Milesi, C., Zhao, M., et al. (2003). User's Guide: GPP and NPP (MOD17A2/A3) Products, NASA MODIS Land Algorithm. Montana: The University of Montana.

Heinsch, F. A., Zhao, M., Running, S. W., Kimball, J. S., Nemani, R. R., Davis, K. J., et al. (2006). Evaluation of remote sensing based terrestrial productivity from MODIS using regional tower eddy flux network observations. IEEE Transactions on Geoscience and Remote Sensing, 44 (7), 1908-1924.

Heitschmidt, R. K., Haferkamp, M. R., Karl, M. G., \& Hild, A. L. (1999). Drought and grazing: I. Effects on quantity of forage produced. Journal of Range Management, 52(5), 440-446.

Heitschmidt, R. K., Klement, K. D., \& Haferkamp, M. R. (2005). Interactive effects of drought and grazing on Northern Great Plains rangelands. Rangeland Ecology and Management, 58(1), 11-19.

Huete, A., Didan, K., Miura, T., Rodriguez, E. P., Gao, X., \& Ferreira, L. G. (2002). Overview of the radiometric and biophysical performance of the MODIS vegetation indices. Remote Sensing of Environment, 83(1-2), 195-213.

Justice, C. O., Vermote, E., Townshend, J. R. G., Defries, R., Roy, D. P., Hall, D. K., et al. (1998). The Moderate Resolution Imaging Spectroradiometer (MODIS): Land remote sensing for global change research. IEEE Transactions on Geoscience and Remote Sensing, 36(4), 1228-1249.

Kramer, K., Leinonen, I., Bartelink, H. H., Berbigier, P., Borghetti, M., Bernhofer, Ch., et al. (2002). Evaluation of six process-based forest growth models using eddy-covariance measurements of $\mathrm{CO}_{2}$ and $\mathrm{H}_{2} \mathrm{O}$ fluxes at six forest sites in Europe. Global Change Biology, 8(3), 213-230.

Lieth, H. (1975). Primary production of the major vegetation units of the world. In H. Lieth \& R.H. Whittaker (Eds.), Primary Productivity of the Biosphere (pp. 203-215). New York: Springer-Verlag.

Novick, K. A., Stoy, P. C., Katul, G. G., Ellsworth, D. S., Siqueira, M. B. S., Juang, J., et al. (2004). Carbon dioxide and water vapor exchange in a warm temperate grassland. Oecologia, 138(2), 259-274.
Omernik, J. M. (1987). Map supplements: Ecoregions of the conterminous United States. Annals of the Association of American Geographers, 77(1), $118-125$.

Parton, W. J., Scurlock, J. M. O., Ojima, D. S., Gilmanov, T. G., Scholes, R. J., Schimel, D. S., et al. (1993). Observations and modeling of biomass and soil organic matter dynamics for the grassland biome worldwide. Global Biogeochemical Cycles, 7(4), 785-809.

Pauwels, V. R. N., \& Samson, R. (2006). Comparison of different methods to measure and model actual evapotranspiration rates for a wet sloping grassland. Agricultural Water Management, 82(1-2), 1-24.

Plummer, S. (2006). On validation of the MODIS gross primary production product. IEEE Transaction on Geoscience and Remote Sensing, 44(7), 1936-1938.

Potter, C. S., Randserson, J. T., Field, C. B., Matson, P. A., Vitousek, P. M., Mooney, H. A., et al. (1993). Terrestrial ecosystem production: A process model based on global satellite and surface data. Global Biogeochemical Cycles, 7(4), 811-841.

Raupach, M. R. (1988). Canopy transport processes. In W. L. Sterffen \& O.T. Denmead (Eds.), Flow and Transport in the Natural Environment: Advances and Applications (pp. 95-127). Berlin: Springer-Verlag.

Reed, B. C., Brown, J. F., Vanderzee, D., Loveland, T. R., Merchant, J. W., \& Ohlen, D. O. (1994). Measuring phenological variability from satellite imagery. Journal of Vegetation Science, 5(5), 703-714.

Running, S. W., Baldocchi, D. D., Turner, D. P., Gower, S. T., Bakwin, P. S., \& Hibbard, K. A. (1999). A global terrestrial monitoring network integrating tower fluxes, flask sampling, ecosystem modeling and EOS satellite data. Remote Sensing of Environment, 70(1), 108-127.

Running, S. W., Nemani, R. R., Heinsch, F. A., Zhao, M., Reeves, M., \& Hashimoto, H. (2004). A continuous satellite-derived measure of global terrestrial primary production. Bioscience, 54(6), 547-560.

Schmid, H. P. (2002). Footprint modeling for vegetation atmosphere exchange studies: A review and perspective. Agricultural and Forest Meteorology, 113(1-4), 159-183.

Sims, P. L., \& Bradford, J. A. (2001). Carbon dioxide fluxes in a southern plains prairie. Agricultural and Forest Meteorology, 109(2), 117-134.

Smart, A. J., Dunn, B., \& Gates, R. (2005). Historical weather patterns: A guide for drought planning. Rangelands, 27(2), 10-12.

Tieszen, L. L., Reed, B. C., Bliss, N. B., Wylie, B. K., \& DeJong, D. D. (1997). NDVI, $C_{3}$ and $C_{4}$ production, and distributions in Great Plains grassland land cover classes. Ecological Applications, 7(1), 59-78.

Tucker, C. J. (1996). History of the use of AVHRR data for land applications. In G. D'Souza, A. S. Belward, \& J. P. Malingreau (Eds.), Advances in the Use of NOAA AVHRR Data for Land Applications (pp. 1-19). Dordrecht, Netherlands: Kluwer Academic Publishers.

Turner, D. P., Guzy, M., Lefsky, M. A., Ritts, W. D., Van Tuyl, S., \& Law, B. E. (2004). Monitoring forest carbon sequestration with remote sensing and carbon cycle modeling. Environmental Management, 33(4), 457-466.

Turner, D. P., Ritts, W. D., Cohen, W. B., Gower, S. T., Zhao, M., Running, S. W., et al. (2003). Scaling gross primary production (GPP) over boreal and deciduous forest landscapes in support of MODIS GPP product validation. Remote Sensing of Environment, 88(3), 256-270.

Turner, D. P., Ritts, W. D., Cohen, W. B., Maeirsperger, T. K., Gower, S. T., Kirschbaum, A. A., et al. (2005). Site-level evaluation of satellite-based global terrestrial gross primary production and net primary production monitoring. Global Change Biology, 11(4), 666-684.

VEMAP Members. (1995). Vegetation/ecosystem modeling and analysis project: Comparing biogeography and biogeochemistry models in a continental-scale study of terrestrial ecosystem responses to climate change and $\mathrm{CO}_{2}$ doubling. Global Biogeochemical Cycles, 9(4), 407-437.

Veroustraete, F., Sabbe, H., \& Eerens, H. (2002). Estimation of carbon mass fluxes over Europe using the C-Fix model and Euroflux data. Remote Sensing of Environment, 83(3), 376-399.

Williams, M., Rastetter, E. B., Fernandes, D. N., Goulden, M. L., Shaver, G. R., \& Johnson, L. C. (1997). Predicting gross primary productivity in terrestrial ecosystems. Ecological Applications, 7(3), 882-894.

Willmott, C. J. (1981). On the validation of models. Physical Geography, 2(2), 184-194. 
Willmott, C. J. (1982). Some comments on the evaluation of model performance. Bulletin of the American Meteorological Society, 63(11), $1309-1313$

Wolfe, R. E., Nishihama, M., Fleig, A. J., Kuyper, J. A., Roy, D. P., Storey, J. C., et al. (2002). Achieving sub-pixel geolocation accuracy in support of MODIS land science. Remote Sensing of Environment, 83(1-2), 31-49.

Wylie, B.K., Fosnight, E.A., Gilmanov, T.G., Frank, A.B., Morgan, J.A., Haferkamp, M.R., et al. (in press). Adaptive data-driven models for estimating carbon fluxes in the Northern Great Plains. Remote Sensing of Environment.

Wylie, B. K., Gilmanov, T. G., Johnson, D. A., Saliendra, N. Z., Akshalov, K., Tieszen, L. L., et al. (2004). Intra-seasonal mapping of $\mathrm{CO}_{2}$ flux in rangelands of Northern Kazakhstan at one-kilometer resolution. Environmental Management, 33(Suppl. 1), S482-S491.

Wylie, B. K., Johnson, D. A., Laca, E., Saliendra, N. Z., Gilmanov, T. G., Reed, B. C., et al. (2003). Calibration of remotely sensed, coarse resolution NDVI to $\mathrm{CO}_{2}$ fluxes in a sagebrush-steppe ecosystem. Remote Sensing of Environment, 85(2), 243-255.

Xiao, X., Hollinger, D., Aber, J., Goltz, M., Davidson, E. A., Zhang, Q., et al. (2004). Satellite-based modeling of gross primary production in an evergreen needleleaf forest. Remote Sensing of Environment, 89(4), 519-534.

Xie, P., \& Arkin, P. A. (1996). Global precipitation: A 17-year monthly analysis based on gauge observations, satellite estimates, and numerical model outputs. Bulletin of the American Meteorological Society, 78(11), 2539-2558.

Zhao, M., \& Running, S. W. (2006). Sensitivity of Moderate Resolution Imaging Spectroradiometer (MODIS) terrestrial primary production to the accuracy of meteorological reanalyses. Journal of Geophysiscal Research, 111, G01002. 